\title{
Matgorzata Ciszewska
}

https://orcid.org/oooo-0002-1937-7284

Instytut Badań Literackich

Polska Akademia Nauk

\section{Dzieweczki i panny $\mathrm{w}$ pogrzebowych mowach szlacheckich i kazaniach (XVII wiek)}

Studium przedstawia analizę porównawczą enkomionów zawartych w oracjach szlacheckich i kazaniach wygłoszonych w XVII stuleciu na pogrzebach dziewczynek i panien. Zestawienie tekstów należących do dwu różnych gatunków stawia zagadnienie wzorów osobowych w nowym świetle, gdyż zależny od rodzaju mowy sposób amplifikacji retorycznej tych samych toposów pochwalnych okazuje się mieć zasadniczy wpływ na wzorzec, jaki wyłania się z mowy.

The study presents a comparative analysis of encomia included in noblemen's orations and sermons delivered in the seventeenth century at the funerals of girls and maidens. The juxtaposition of texts belonging to two different genres places the issue of role models in a new light because the way of rhetorical amplification of the same laudatory topoi, which depends on the type of speech, turns out to have a fundamental influence on the model that emerges from the speech.

Słowa kluczowe: oratorstwo staropolskie, kazania pogrzebowe, szlacheckie mowy pogrzebowe, pochwała panny

Ke yw ord s: Old Polish oratory, funeral sermons, funeral noble's speeches, encomium of a maiden 
Panna, choćby najwdzięczniejsza, nie była wdzięcznym obiektem pochwały funeralnej w kulturze staropolskiej. Trudności inwencyjne, które napotykał orator, związane były przede wszystkim z bardzo szczupłym katalogiem cnót panieńskich godnych laudacji. Zestaw ów stanowił bowiem uboższą wersję i tak już mało zróżnicowanego i skromnego zbioru zalet kobiecych (pobożności, roztropności, stateczności etc.), okrojonego ze wszystkich wiązanych tradycyjnie z rolą żony i matki ${ }^{1}$. Mimo to niektórzy mówcy potrafili nawet $\mathrm{z}$ tak niewielu dostępnych toposów pochwalnych skomponować obszerny enkomion. Niniejsze studium jako pierwsze przedstawia analizę porównawczą mów szlacheckich i kazań wygłoszonych na pogrzebach panien w wieku XVII.

Mowa pogrzebowa to termin genologiczny, który jest używany w odniesieniu do trzech zasadniczo odmiennych gatunków oratorskich: kazania pogrzebowego, humanistycznej mowy funeralnej i nieporównanie młodszej szlacheckiej mowy pogrzebowej ${ }^{2}$. Trzy te

1 Obszerne zestawienie bibliograficzne dotyczące tematyki kobiet, wychowania i rodziny w dawnych wiekach w: M. Bogucka, Biatogtowa $w$ dawnej Polsce. Kobieta w spoteczeństwie polskim XVI-XVIII wieku na tle porównawczym, Warszawa 1998, s. 9-33. Nowsze publikacje poświęcone tej tematyce, m.in: D. Żołądź-Strzelczyk, Dziecko w dawnej Polsce, Poznań 2002; Ł. Charewiczowa, Kobieta $w$ dawnej Polsce: do okresu rozbiorów, Poznań 2002; K. Górecka, Pobożne matrony i cnotliwe panny. Epitafia jako źródto wiedzy o kobiecie w epoce nowożytnej, Warszawa 2006; E. Kahl, Wychowanie dziecka w rodzinie szlacheckiej w XVI i XVII wieku, „Wychowanie w Rodzinie”, 1, 2011, s. 19-38; J. Kuchta, W godności i w cnoty dojrzate - o wzorcu panny, żony i dobrego matżeństwa $w$ literaturze okolicznościowej XVII-XVIII wieku, „Annales Universitatis Paedagogicae Cracoviensis", Folia 95, Studia Historica, 10, 2011, s. 57-65. Opracowania na bazie źródeł homiletycznych zob. U. Kicińska, Wzorzec szlachcianki w polskich drukowanych oracjach pogrzebowych XVII wieku, Warszawa 2013; eadem, Pobożność szlachcianki w świetle polskich drukowanych mów pogrzebowych XVII wieku, „Folia Historica Cracoviensia”, 18, 2012, s. 213-237; A. Nowicka-Struska, Obrazy kobiety i kobiece wzorce osobowe w siedemnastowiecznych kazaniach pogrzebowych autorstwa karmelitów bosych, „Wschodni Rocznik Humanistyczny”, 3, 2006, s. 57-68.

2 O rozróżnieniach tych gatunków zob. M. Skwara, Polskie drukowane oracje pogrzebowe XVII wieku. Bibliografia, Gdańsk 2009, s. 9, 15-94; M. Ciszewska, Tuliusz domowy. Świeckie oratorstwo szlacheckie kregu rodzinnego (XVII-XVIII wiek), Warszawa 2016, s. 11-12; E. Danowska, J. Wojtowicz, Kazania i mowy pogrzebowe w XVIII wieku na podstawie starodruków Biblioteki Naukowej PAU i PAN w Krakowie, w: Europejski wiek osiemnasty. Uniwersalizm myśli, różnorodność dróg. Studia i materiaty, Warszawa-Kraków 2014, s. 524-525. Termin oratio funebris najczęściej jednak (jak wynika z bibliografii: J. M. McManamon SJ, 
gatunki mimo pozornego podobieństwa wynikającego $\mathrm{z}$ analogicznych okoliczności towarzyszących ich wygłaszaniu, faktycznie bardzo się różnią: genezą, celem, sposobem funkcjonowania, w końcu nawet pozycją i rolą społeczną mówcy. Oracje szlacheckie w przeciwieństwie do kazań miały charakter wyłącznie świecki, w kontraście zaś do mów humanistycznych były bez wyjątku w języku wernakularnym. Jednocześnie w opozycji do obu tych gatunków co do zasady istniały w dialogu (mowa od gości - oratio ab hospitibus ${ }^{3}$ i dziękowanie $\mathrm{w}$ imieniu rodziny - oratio gratiarum actoria bądź oratio nomine consanguineorum $)^{4}$, odgrywały faktyczną rolę komunikacyjną i organizacyjną ${ }^{5}$, wygłoszenie ich było bezkosztowe ${ }^{6}$, a także pozostawały $\mathrm{w}$ nierozdzielnym związku z fizycznym i ceremonialnym kontekstem

An Incipitarium of Funeral Orations and a Smattering of Other Panegyrical Literature from the Italian Renaissance (ca. 1350-1550), http://www.luc.edu/media/ lucedu/history/pdfs/Incipit_Catalogue.pdf; 9 III 2016) był używany przez autorów mów humanistycznych.

3 O gatunku wraz z bibliografią przedmiotu zob. M. Ciszewska, Tuliusz domowy, s. 216-234.

4 O gatunku zob. ibidem, s. 234-249. Alternatywnie do terminu „mowa od gości” wraz z M. Barłowską zaproponowałyśmy termin „kondolencja od gości”, w odniesieniu zaś do terminu „dziękowanie w imieniu rodziny” - „dziękowanie na pogrzebie”; M. Barłowska, M. Ciszewska, Wprowadzenie do lektury, w: J. Sobieski, Mowy pogrzebowe, wyd. M. Barłowska, M. Ciszewska, Warszawa 2019, s. 22-29.

5 W dziękowaniu na pogrzebie w trzeciej części oracji mówca zaprasza uczestników pogrzebu na stypę.

6 Wygłoszenie zarówno kazania, jak i mowy humanistycznej było w większości płatne; zob. rachunki z pogrzebów, np. J. A. Chrościcki, Pompa funebris. $Z$ dziejów kultury staropolskiej, Warszawa 1974, s. 270; S. Ochmann, Pogrzeb magnata $w$ XVII wieku w świetle rachunków, w: $Z$ dziejów i tradycji Srebrnego Wieku. Studia $i$ materiaty, red. J. Pietrzak, Wrocław 1990 (Acta Universitatis Wratislaviensis. Historia, t. 75, nr 1108), s. 75; S. Baczewski, Mit poczatku i wtadza szlachty. Dyskurs genealogiczno-historyczny w XVII-wiecznych kazaniach pogrzebowych, "Wschodni Rocznik Humanistyczny”, 3, 2006, s. 41. O stawkach za orationes funebres we Włoszech zob. J. M. McManamon SJ, Funeral Oratory and the Cultural Ideals of Italian Humanism, Chapel Hill 1989, s. 27. O kulisach tworzenia „na zamówienie” utworów funeralnych poświęconym Radziwiłłom i ujmowaniu tego zjawiska w kategoriach klientyzmu lub serwitoratu zob. M. Jarczykowa, Sponsorowana pochwata. Funeralia Radziwittowskie z XVII wieku napisane na zamówienie, „Napis”, 25, 2019, s. 19-36. „Mowy humanistyczne” powstawały jednak też często jako wyraz wdzięczności dla dobroczyńcy, albo sua sponte z podziwu dla wybitnej osobowości. Mowy szlacheckie wygłaszali przyjaciele rodziny lub krewni zmarłego, nie towarzyszyły temu żadne sformalizowane relacje finansowe, choć nie można wykluczyć uznaniowej gratyfikacji w podziękowaniu za „przyjacielską” przysługę. 
uroczystości ${ }^{7}$. O ile bowiem mowy humanistyczne i kazania mogły funkcjonować wtórnie lub nawet wyłącznie jako teksty pisane (drukowane $)^{8}$, o tyle oracje szlacheckie nigdy nie zmieniły przynależności rodzajowej, nie stały się gatunkami stricte literackimi, ich prymarnym, inherentnym celem zawsze była i pozostała actio, czego konsekwencją jest ich nieobecność w obiegu drukowanym ${ }^{9}$ (przy jednoczesnej ewidentnej nadreprezentacji $\mathrm{w}$ obiegu rękopiśmiennym ${ }^{10}$, w który były wprowadzane ex post). W porównaniu ze starszymi gatunkami oracje szlacheckie są też dużo krótsze - ich wygłoszenie, poza wyjątkami, nie trwało zazwyczaj dłużej niż około dwadzieścia minut, podczas gdy kazania i mowy humanistyczne liczyły w druku nawet ponad pół setki stron ${ }^{11}$.

Nie jest jednak wykluczone, że mowy szlacheckie wykształciły się właśnie z oracji humanistycznych albo że to za ich pośrednictwem przyjęły z Rhetorica ad Herennium trójdzielny model panegiryku oraz biografizm ${ }^{12}$. Zarówno kondolencja, jak i dziękowanie na pogrzebie zbudowane są ze wstępu, zazwyczaj o charakterze filozoficzno-

7 Zob. podobne uwagi związku z oratorskim hic et nunc w odniesieniu do encomium w okresie późnego imperium rzymskiego zob. L. Pernot, Epideictic Rhetoric. Questioning the Stakes of Ancient Praise, Austin 2015, s. 13; o bizantyjskim epitafiosie zob. E. C. Bourbouhakis, Not Composed in a Chance Manner. The Epitaphios for Manuel I Komnenos by Eistathios of Thessalonike, Uppsala 2017 (Acta Universitatis Upsaliensis. Studia Byzantina Upsaliensia, t. 18), s. 43-47.

${ }^{8}$ Na przykłady Kazań sejmowych Piotra Skargi oraz „mów” pogrzebowych Kromera i Orzechowskiego jako tekstów literackich zwraca uwagę J. Starnawski; idem, Wstęp, w: S. Orzechowski, Wybór pism, oprac. J. Starnawski, Wrocław 1972, s. XVIII; idem, Wstep, w: M. Kromer, Mowa na pogrzebie Zygmunta I oraz O pochodzeniu i o dziejach Polaków ksieggi XXIX i XXX, oprac. J. Starnawski, Olsztyn 1982, s. XXI.

9 W bibliografii M. Skwary (idem, Polskie drukowane oracje pogrzebowe) drukowanym mowom szlacheckim poświęconych jest zaledwie kilkanaście stron (z których większość zajmują przekazy oracji w antologii Jana Pisarskiego Mówca polski), wobec kilkuset odnotowujących kazania.

${ }_{10} \mathrm{O}$ zbiorach oratorskich i funkcjonowaniu tekstów oracji szlacheckich w obiegu rękopiśmiennym zob. M. Barłowska, Swada i milczenie. Zbiory oratorskie XVII-XVIII wieku - prolegomena filologiczne, Katowice 2010, passim.

$11 \mathrm{~W}$ swych początkach humanistyczne orationes funebres również były stosunkowo krótkie, gdyż czas przemawiania limitował scenariusz pogrzebu. W Italii było to zazwyczaj około pół godziny; zob. J. M. McManamon, SJ, Funeral Oratory, s. 28.

12 Jest to teza, której przy obecnym stanie znajomości źródeł szesnastowiecznych nie da się udowodnić, z uwagi jednak na chronologię nie da się jej również wykluczyć. Najstarszą, a zarazem jedyną znaną z XVI stulecia mową szlachecką jest Przy pogrzebie rzecz Jana Kochanowskiego (1576). Dodać tu należy, że schemat trójdzielny nie był jedynym funkcjonującym w pierwszej połowie XVII stulecia, źródła dla pozostałych modeli pozostają na razie nierozpoznane. 
-refleksyjnym ${ }^{13}$, i pochwały zmarłego. Ich differentia specifica, która jednocześnie czyni te mowy wobec siebie komplementarnymi, tkwi w conclusio: w kondolencji jest to wyrażenie współczucia i pocieszenie, w dziękowaniu - symetryczne wyrażenie wdzięczności za obecność i wystąpienia kondolencyjne oraz ( $\mathrm{w}$ zależności od scenariusza uroczystości) zaproszenie na stypę.

Autorzy staropolskich podręczników wymowy nie tylko opisywali szczegółowo każdy gatunek i każdą odmianę gatunkową oracji, ale również ilustrowali osobnymi wykładami i przykładami tak szczegółowe zagadnienia, jak dostosowanie wystąpienia do godności, statusu społecznego, wieku i płci osoby zmarłej. W pochodzącym z połowy XVII w. rękopiśmiennym traktacie Orator Tullianus politicus seu Instructiones oratoriae Ciceronis oratori utriusque status nobili accommodatae znajdujemy drobiazgowy opis mowy na pogrzebie panny ${ }^{14}$. Ponieważ ten fragment wykładu nie był jeszcze cytowany w opracowaniach, pozwolę sobie na obszerniejsze przytoczenia.

Exordium winno mieć charakter refleksji wanitatywnej wyprowadzonej z toposu „życie ludzkie jak kwiat”, który następnie ma ustąpić toposowi „dziewictwo jak kwiat”:

Itaque in exordio universaliter comparare possis vitam humanam flori, idque ex doctorum sententia, quae thesis esset roboranda authoritate aliqua, aut symbolo. In confirmatione vero precipue similitudinem hanc competere virginitati, sua inconstantia et vitae brevitate florem representanti ${ }^{15}$.

Warto tu zwrócić uwagę, że retor bynajmniej nie zaleca amplifikacji argumentów wyprowadzanych ze zwyczajowych toposów egzordialnych ${ }^{16}$. Nie proponuje ani przedstawienia istoty i celu mowy

13 Dostrzega to już w mowie Kochanowskiego M. Barłowska; eadem, „Nasz Kochanowski". Studia z recepcji poety w wieku XVII, Katowice 2014, s. 19-18.

14 Punctum 7-timum. De oratione dicenda in funere virginum et matronarum [O mowie, jaką należy wygłosić na pogrzebie panien i matron], rkps, BJ, sygn. 6092, k. 135rec.-ver. Inne zagadnienia z tego obszernego wykładu, zob. M. Ciszewska, Tuliusz domowy, s. 212, 214, 221, 226, 234-236, 418.

15 „W uzasadnieniu zaś porównanie to [mógłbyś/possis] zastosować zwłaszcza do dziewictwa, ze względu na niestałość i krótkotrwałość życia przedstawiającego / symbolizującego kwiat”, BJ, rkps 6092, k. 135rec. Jeśli nie zaznaczono inaczej, wszystkie uzupełnienia, komentarze i podkreślenia w cytowanych źródłach i ich tytułach pochodzą od autorki. Jeśli nie wskazano inaczej, tłumaczenia cytatów również pochodzą od autorki.

16 T. Bieńkowski, Proemium (Antyczna teoria wstępu do mowy), „Meander”, 1965, 1, s. 19. 
pogrzebowej, ani pozyskania przychylności słuchaczy przez wyrażenie skromności mówcy. Oba te tematy, proweniencji antycznej, przez wieki uważane za jeśli nie obowiązkowe, to przynajmniej bardzo istotne, mówcy szlacheccy traktowali jako fakultatywne. Motyw autorskiej samoświadomości retorycznej replikowały kolejne generacje mówców pogrzebowych ${ }^{17}$, jednak staropolscy oratorzy szlacheccy przywoływali go nie częściej niż inne, uznane przez nich za równie stosowne. Podobnie było z toposem modestiae oratoris, który choć obecny jeszcze w humanistycznej oratio funebris, w tradycji szlacheckiej amplifikowany był głównie przez bardzo młodych, nastoletnich mówców ${ }^{18}$. W exordium dziękowania czy kondolencji pojawiały się za to loci communes zwyczajowo uważane za konsolacyjne, takie jak wymienione przez Menandra z Laodycei w odniesieniu do paramythetikos (lub paramuthetikos) logos (mowy pocieszającej): „śmierć jako boski wyrok”, „powszechność śmierci”, „śmierć jako sposób uniknięcia trosk i chorób" etc. ${ }^{19}$. Zadaniem wywiedzionych z nich argumentów nie było jednak pocieszenie zebranych, ale zbudowanie poczucia emocjonalnej więzi między mówcą i audytorium, wytworzenie swoistej wspólnoty doświadczenia.

W confirmatio winna nastąpić pochwała:

In 2-da parte confirmationis virginem defunctam assimulare posses variis floribus, nunc lilio, nunc rosae, assimulationis tamen huiusque essent rationes dandae, petitae ex virtutibus eius, aut certe ex splendore familiae ${ }^{20}$.

17 E. C. Bourbouhakis, op. cit., s. 32.

18 M. Ciszewska, Modestia mtodego mówcy (XVII-XVIII wiek), w: Sarmackie theatrum, VIII. W poszukiwaniu nowości, red. M. Barłowska, M. Walińska, Katowice 2020, s. 26-49.

19 Men. Rhet. 2, 9 (414, 2-27), numeracja za edycją: Menander Rhetor, ed., transl., comm. D. A. Russell, N. G. Wilson, Oxford 1981; zob. M. R. P. McGuire, The Early Christian Funeral Oration, w: Funeral Orations by Saint Gregory Nazianzen and Saint Ambrose, transl. L. P. McCauley SJ, J. J. Sullivan C.S.Sp., M. R. P. McGuire, R. J. Deferrari, Washington 2017 (repr. ed. 1968) (The Fathers of the Church, t. 22), s. XII-XIII. O toposie „śmierć jest powszechna” zob. M. Skwara, "Miejsca wspólne” polskiej poezji i sztuki funeralnej XVI i początku XVII wieku, Szczecin 1994, s. 53.

20 „W drugiej części uzasadnienia mógłbyś porównać zmarłą pannę do różnych kwiatów, a to do lilii, a to do róży, jednak należy podać powody tego porównania, zaczerpnięte z jej [panny] cnót albo niewątpliwie ze znakomitości jej rodu”, BJ, rkps 6092, k. 135rec.-ver. 
Powyższy projekt części laudacyjnej zwraca uwagę swoją ogólnością: mówca ma kontynuować amplifikację symboliki floralnej, same zaś argumenty pochwalne winny być formułowane $\mathrm{z}$ uwagi na cnoty (ex virtutibus), nie zaś ze względu na zasługi (ex meritis, ex factis). O ile pochwała rodu (ex genere) jest wspólnym elementem wszystkich mów szlacheckich niezależnie od płci, wieku i godności osoby zmarłej, o tyle w przypadku pozostałych toposów widać wyraźny rozdział: ojców, mężów i synów chwali się przede wszystkim za ich szczegółowo opisywane dokonania in toga et in sago, kobiety zaś niemal wyłącznie ze względu na cnoty. Te dwa odmienne porządki to tysiącletnie dziedzictwo, które wymowa szlachecka przyjęła, gdyż idealnie wpisywało się w patriarchalną wizję społeczeństwa. Pierwszym oratorem, który uczcił kobietę, swoją siostrę Gorgonię, epitafiosem (a zatem mową pogrzebową o bardzo oficjalnym charakterze) był Grzegorz z Nazjanzu ${ }^{21}$. Do tego momentu od początku historii w epitafios logos bohaterami oracji byli wyłącznie mężczyźni, kobiety wzmiankowano jedynie w kontekście płaczu i lamentu lub jako adresatki końcowych pouczeń $^{22}$. Teolog stanął więc przed problemem adaptacji silnie zmaskulinizowanej topiki pochwalnej do potrzeb enkomionu kobiecego. Porzucił porządek chronologiczny obowiązujący dotąd w epitafiosach na rzecz porządku cnót. W efekcie w tekście wystąpienia brakuje podstawowych informacji biograficznych, nawet imion męża i dzieci laudaty. Tomas Hägg bardzo trafnie definiuje to nowe ujęcie: życiorys mężczyzny był komponowany jako następstwo faktów, które miały ujawniać jego zalety, kobiety natomiast (w tym przypadku Gorgonia) były zawieszone w bezczasowym continuum, ich cnoty zaś miały się objawiać jednocześnie ${ }^{23}$. Pochwała siostry Teologa rzeczywiście zorganizowana jest wokół cnót, cnót - dodam - typowo kobiecych (czystość i wierność małżeńska, gospodarność, skromność w stroju, wiara i pobożność, gościnność i miłość bliźniego etc.), ale każdą z nich mówca obszernie amplifikuje argumentami o charakterze biograficznym. Grzegorz relacjonuje dokonania siostry - kobiety bardzo czynnej i biorącej aktywny udział w życiu społeczności wyznaniowej, a nawet

21 Patrologia Graeca, t. 35, ed. J.-P. Migne, Paris 1857, s. 789-817. Mowa powstała między 369 a $374 \mathrm{r}$.

22 Por. V. Burrus, Life after Death. The Martyrdom of Gorgonia and the Birth of Female Hagiography, w: Gregory of Nazianzus. Images and Reflections, ed. J. Børtnes, T. Hägg, Copenhagen 2006, s. 153-170, s. 153 n.

23 Por. T. Hägg, Playing with Expectations. Gregory's Funeral Orations on His Brother, Sister and Father, w: ibidem, s. 145. 
cytuje jej słowa wypowiadane w różnych okolicznościach. Gorgonia jest więc postacią żywą i działającą. Tymczasem pochwały polskich i litewskich szlachcianek to przede wszystkim wyliczenia cnót pozbawione egzemplifikacji ${ }^{24}$. W przypadku zmarłych dziewcząt enumeracje te bywały jeszcze skromniejsze, gdyż stanowiąc niewykorzystany potencjał rodu ${ }^{25}$, panny nie zdążyły się wykazać cnotami mężatki, matki ani wdowy.

Conclusio, czyli zakończenie, łączy w traktacie cechy kondolencji i dziękowania ${ }^{26}$. W praktyce oratorskiej otuchy rodzinie zmarłej dodawali mówcy występujący w imieniu gości, reprezentanci krewnych w dziękowaniu mogli jedynie potwierdzić, że nadzieja zbawienia i obecność tak zacnych gości w istocie przynosi im (tj. bliskim) ulgę. Z kolei na stypę (ad lugubre convivium) goście nie mogli zapraszać krewnych zmarłej, którzy ten bankiet organizowali - kwestia ta mogła więc zostać wygłoszona jedynie przez przemawiających w imieniu rodziców.

Cały cytowany tu fragment poprzedza passus, który celowo przytoczę na końcu prezentacji traktatu. Jest to ogólne przedstawienie zakresu tematycznego samego enkomionu:

${ }^{24}$ Zamknięcie kobiety w perspektywie prywatnej uległo niejakiej zmianie w niektórych mowach humanistycznych. W drugiej połowie XV stulecia mówcom funeralnym zdarzało się chwalić niewiasty m.in. za zdolności oratorskie i humanistyczną edukację, ale także za umiejętność zarządzania prowincją czy miastem pod nieobecność swego książęcego małżonka lub syna. Przykładowo Battista Sforza, księżna Urbino, sławiona była pośmiertnie ze względu na jej wyjątkowy talent krasomówczy, gdyż już jako czterolatka potrafiła wygłosić mowę w języku łacińskim. Eleonora Aragońska, księżna Ferrary, Modeny i Reggio, była sprawną i sprawiedliwą regentką męża, Elisabetta Malatesta zyskała zaś szacunek senatu Pesaro dzięki swym wnikliwym i elegancko wyrażanym uwagom. Pochwały te stanowiły jednak jedynie dodatek do laudacji opartej na tradycyjnych wartościach; por. J. M. McManamon SJ, Funeral Oratory, s. 113, 225-226. Trzeba tu jednak przyznać, że za elokwencję w oracji świeckiej chwalona była również Anna z Kostków Ostrogska; zob. J. Sobieski, XVIII. Dziękowanie na pogrzebie Anny Ostrogskiej z Kostków, w: idem, Mowy pogrzebowe, s. 104 (XVIII, 41).

25 A. Nowicka-Struska, op. cit., s. 59-60.

26 „In conclusione vero maesti parentes defunctae virginis spei suae, et fulcri senectutis, essent in consolationem erigendi, vel inde, quod probae educationis suae solam filiam in felicis aeternitatis regionem permiserint, ad extremum gratiae agendae more solito hospitibus et <pete>ndi [uzup. M.C.; rkps - nieczytelne] ad lugubre convivium” („W zakończeniu zaś należy dodać otuchy zbolałym rodzicom zmarłej panny, ich nadziei i podpory na starość, na przykład od tego [wyjśćc, że swoją córkę wysłali/skierowali do krainy szczęśliwej/błogosławionej wieczności. Na końcu przyjętym obyczajem należy podziękować gościom i zaprosić na żałobny poczęstunek"), BJ, rkps 6092, k. 135ver. 
Non nisi in laudando sexu, haec laudatio differt a laudatione funebri adolescentis cuiuspiam aut pueri, proinde quae ibi dicta sunt et hic serviunt, valent autem potissimum comparationes a floribus, plantis, hortis et aliis rebus delicatioribus, fiunt et apostrophes et commiserationes ad parentes, quod cum illi sperassent suo tempore ex filia posteritatem et iam ornatum muliebrem, preciosos parassent sumptus, iam conquirerent dotem, mors haec omnia precedit et uno sepulchro cum lectissima filia consepelivit, brevissimeque orator excurrere ${ }^{27}$ potest in laudem virginitatis, quae dos est angelica et hominem facit Deo simillimum. Ubi pergratulabitur virgini, quod nullis fatigata matrimonii incommodis, angelicis mentibus et sponso puritatis sit coniuncta ${ }^{28}$.

Topos kwiatu w tym kontekście ma oczywiście proweniencję biblijną ${ }^{29}$, o ile jednak w tradycji oratorstwa funeralnego był źródłem argumentów przede wszystkim lamentacyjnych ${ }^{30}$, o tyle w wymowie szlacheckiej czerpano z niego argumenty głównie pochwalne i refleksyjne.

Podobna zmiana dokonała się w zakresie potencjału konsolacyjnego toposu niedoszłego małżeństwa przez Menandra wskazywanego jako charakterystyczny dla monodii (mowy lamentacyjnej) poświęconej młodzieńcowi. Retor zalecał, aby taki threnos amplifikować przez ekspresję bólu niespełnionych nadziei wiązanych z mariażem. Sugerował również wykorzystanie motywu weselnej alkowy,

27 excurrere - popr. M.C.; excurreret - rkps.

28 „W niczym prócz chwalenia płci mowa taka nie różni się od pogrzebowej pochwały jakiegoś młodzieńca czy chłopca, dlatego też to, co tam zostało powiedziane, posłuży i tutaj. Najwięcej zaś wyrazu mają porównania wywodzące się od kwiatów, roślin, ogrodów i innych bardzo subtelnych rzeczy; mają tu miejsce także apostrofy i współczucie wobec rodziców, ponieważ kiedy oni mieli nadzieję na potomstwo [dosłownie: potomność/przyszłość] z córki we właściwym czasie i już zgromadzili kobiece stroje, niemałe pieniądze, już zabiegali wokół posagu, śmierć uprzedziła to wszystko i w jednym grobie z najukochańszą córką pogrzebała. Następnie mówca może przejść w krótkich słowach do pochwały dziewictwa, które jest anielskim posagiem i czyni człowieka podobnym Bogu. Wtedy powinszuje pannie, że nie znużona żadnymi niedogodnościami małżeństwa, złączyła się z anielskimi duchami i oblubieńcem czystości”, BJ, rkps 6092, k. 135rec. Hi 14, 2; PnP 2, 1-2; Ps 103,15; Iz 40, 6-7; 1 P 1, 24.

30 Jako pierwszy spośród oratorów funeralnych w ten sposób wykorzystał go Grzegorz z Nyssy w mowie pocieszającej (paramutetikos logos) wygłoszonej w 385 r., po śmierci cesarskiej córeczki, sześcioletniej Pulcherii. Porównał w niej śmierć dziewczynki do odlotu gołąbka z gniazda i do obumarcia kwiatu, który nie zdążył się rozwinąć w pełni. O wpływie mów Grzegorza z Nyssy na rozwój humanistycznej oracji funeralnej zob. M. R. P. McGuire, op. cit., s. XIX; M. Skwara, Polskie drukowane oracje pogrzebowe, s. 41. 
która na zawsze miała pozostać już pusta ${ }^{31}$. Wczesne chrześcijaństwo, z trudem godzące lamentację $\mathrm{z}$ wiarą w zbawienie, często rezygnowało $\mathrm{z}$ tej pierwszej ${ }^{32} \mathrm{i} \mathrm{z}$ tych samych loci communes wywodziło argumenty pocieszające. W epitafiosie ku czci swojego brata Cezarego (369 r. n.e.) Teolog sprzeczał się z fikcyjnym rozmówcą, ten bowiem dowodził, że fakt, iż zmarły nie założył rodziny, jest powodem do żalu. Odpowiedź mówcy była bardzo logiczna: Cezary nie zazna cierpienia stającego się udziałem rodziców w przypadku utraty potomstwa, a z drugiej strony sam osieroconych dzieci nie skaże po własnej śmierci na łaskę obcych ${ }^{33}$. Znacznie dalej, w duchu wiary w zbawienie, postąpił Nysseńczyk w konsolacji po śmierci sześcioletniej Pulcherii. W bardzo podobnej diatrybie ${ }^{34}$ odrzucał on identyczne argumenty lamentacyjne, dowodząc, iż prawdziwego szczęścia zmarła dziewczynka zazna u boku Boskiego Oblubieńca, a ponieważ szczęście to będzie wieczne, nigdy nie doświadczy cierpień wdowieństwa ${ }^{35}$.

Mówcy szlacheccy wygłaszali więc pochwały i pocieszenia zgodne z nauką chrześcijańską i obowiązującą ideologią, choć poniekąd wbrew realiom społecznym ${ }^{36}$. W tych ostatnich bowiem ceniono dziewictwo i czystość jedynie jako stan „przejściowy”, posag wniesiony mężowi. Panieństwo poza furtą klasztorną nie znajdowało uznania w oczach społeczeństwa.

31 Men. Rhet. 2, 16 (434,19-435,7).

32 D. Platt, Kazania pogrzebowe z przetomu XVI i XVII wieku. Z dziejów prozy staropolskiej, Wrocław 1992, s. 6; T. Hägg, op. cit., s. 137; M. R. P. McGuire, op. cit., s. XVII.

33 „Nie będzie miał żony ani dzieci? - Ale i nie będzie ich opłakiwać ani nie będzie przez nich opłakiwany, zostawiając ich na łasce innych, albo zostając po nich jako pomnik nieszczęścia”, Grzegorz z Nazjanzu, Mowa 7. Na cześć brata swojego Cezarego, w: J. M. Szymusiak SJ, Grzegorz Teolog. U źródet chrześcijańskiej myśli w IV wieku, przedm. H. de Lubac SJ, Poznań 1965 (Starożytna Myśl Chrześcijańska, t. 1), s. 301 (7, 20).

34 L. Małunowiczówna, Konsolacja w mowach pogrzebowych św. Grzegorza z Nyssy, „Roczniki Humanistyczne”, 23, 1975, 3, s. 89.

35 „A gdyby doszła - powie ktoś - do odpowiedniego wieku, mogłaby się cieszyć małżeńskim szczęściem? Na to odpowie ci prawdziwy Oblubieniec, iż lepsze są niebieskie pokoje małżeńskie, milsze łoże, gdzie nie ma obawy przed wdowieństwem”, Grzegorz z Nyssy, Mowa nad grobem księżniczki Pulcherii, w: idem, Wybór pism, tł. W. Kania, Warszawa 1974 (Pisma Starochrześcijańskich Pisarzy, t. 14), s. 97-98 (3).

36 O rozdźwięku między tymi dwiema sferami zob. A. Wyrobisz, Staropolskie wzorce rodziny $i$ kobiety - żony $i$ matki, „Przegląd Historyczny”, 83, 1992, 3, s. 421. 
Zabytków szlacheckiej wymowy na panieńskich pogrzebach nie zachowało się wiele. Wśród odnalezionych jest pięć tekstów mów tzw. historycznych (faktycznie wygłoszonych) ${ }^{37}$ :

1. między 1607 a 1618 r.: Przemowa [Szczęsnego Kryskiego] na pogrzeb Jej M[oś]ci Panny podkanclerzanki [Anny (?) Mińskiej], Biblioteka Muzeum Narodowego w Krakowie (dalej: MNK), rkps 187, s. $352-354^{38}$;

2. pierwsza połowa XVII w.: Mowa na pogrzebie Jej M[ości] Panny Ponętowskiej, pokojowej Królowej Jej M[oś]ci, Lietuvos valstybès istorijos archyvas (Litewskie Państwowe Archiwum Historyczne w Wilnie; dalej: LVIA), f. 1135, op. 2/40, k. 85rec.;

3. pierwsza połowa XVII w.: Dziękowanie na pogrzebie Jej M[oś]ci Panny Wulfianki, LVIA, f. 1135, op. 2/40, k. 114rec.;

4. pierwsza połowa XVII w.: Druga na pogrzebie także pokojowej Królowej Jej M[oś]ci, LVIA, f. 1135, op. 2/40, k. 114rec.;

5. ca 1660 r.: Mowa tegoż J[ego] M[ości] Pana w[ojewo]dy trockiego [Marcjana Aleksandra Ogińskiego] na pogrzebie Jej M[ości] Pani trockiej [Zuzanny z Gosiewskich 1. voto Sapieżyny, 2. voto Wilczkowej] i córki oraz [Anny] Sapieżanki, pisarzowej W[ielkieg]o Ks[ięstw]a Lit[ewskieg]o, MNK, rkps 425 III, s. 277-279 (według nowej numeracji);

oraz 11 wzorów retorycznych:

1. pierwsza połowa XVII w.: Na pogrzebie zmartej córki, LVIA, f. 1135, op. 2/40, k. 115ver.-116ver. (wzór retoryczny lub przekształcona mowa historyczna);

2. pierwsza połowa XVII w.: Na pogrzebie panny, LVIA, f. 1135, op. 2/40, k. 144rec. (wzór retoryczny lub przekształcona mowa historyczna);

3. pierwsza połowa XVII w.: Respons potym, LVIA, f. 1135, op. 2/40, k. 144rec.-144ver. (wzór retoryczny lub przekształcona mowa historyczna);

37 Serdecznie dziękuję Pani Profesor Marii Barłowskiej za pomoc w skompletowaniu tego zestawienia.

$38 \mathrm{~W}$ niniejszym opracowaniu tekst będzie cytowany za tym przekazem. Inne: $\mathrm{BCz}$, rkps 1679 IV, s. 108-109; BN, rkps 6640, k. 94rec-94ver.; BO, rkps 4589 I, s. 36-37; LVIA, f. 1135, op. 2/40, k. 93ver. (fragment). Liczbę tę trudno uznać za ostateczną. Z pewnością dalsze badania ujawnią więcej przekazów. O kwestii „wzoru retorycznego” i „mowy historycznej” zob. M. Trębska, Staropolskie szlacheckie oracje weselne. Genologia, obrzęd, źródta, Warszawa 2008, s. 472; M. Barłowska, Swada i milczenie, s. 10. 
4. przed 1632 r.: Mowa przy pogrzebie panny, w: Spizarnia aktów rozmaitych, które sie przy zalotach, weselach, bankietach, pogrzebach i tym podobnych inszych zabawach swieckich odprawować zwykty [--], Kraków, 1638, k. F $F_{1}$ ver.-F $\mathrm{F}_{2}$ rec. (wzór retoryczny lub przekształcona mowa historyczna) ${ }^{39}$;

5. przed 1632 r.: Mowa przy pogrzebie mtodzieńca [pod tekstem kursywą podpis: „Taż mowa przy pogrzebie panny odprawowana być może według rozsądku mówiącego; o tym niżej”], w: ibidem, k. $\mathrm{E}_{3}$ ver.- $\mathrm{E}_{4}$ ver. (wzór retoryczny lub przekształcona mowa historyczna);

6. pierwsza połowa XVII w.: Praxis in funere virginis, BJ, rkps 6092, k. 135ver.-136ver. (wzór retoryczny) ${ }^{40}$;

7. K. Wojsznarowicz, Mowa na pogrzeb jakiej panny. Pierwsza, w: idem, Orator polityczny, weselnym i pogrzebowym stuzacy aktom, tak stanowi duchownemu, jako rycerskiemu potrzebny [--], na trzy częsci rozdzielony [--], Kraków 1648, s. 133-134 (wzór retoryczny);

8. idem, Mowa w tejże materyjej wtóra, w: ibidem, s. 135-136 (wzór retoryczny);

9. idem, Mowa $w$ tejże materyjej trzecia, w: ibidem, s. 136-137 (wzór retoryczny);

10. idem, Mowa $w$ tejże materyjej czwarta, w: ibidem, s. 137-138 (wzór retoryczny);

11. idem, Mowa $w$ tejże materyjej piata, w: ibidem, s. 138-13941 (wzór retoryczny).

Jeden $\mathrm{z}$ najobszerniejszych enkomionów znajdujemy $\mathrm{w}$ dziękowaniu wygłoszonym przez wybitnego oratora czasu Wazów, Szczęsnego Kryskiego (1562-1618), podkanclerzego koronnego (1609-1613) i kanclerza wielkiego koronnego (1613-1618), na pogrzebie Anny Mińskiej, podkanclerzanki koronnej, córki zmarłego w 1607 r. Stanisława, herbu Prus III ${ }^{42}$. Terminus post quem wystąpienia to rok

39 Pierwsze wydanie Spiżarni ukazało się w 1632 r., w niniejszym opracowaniu wszelkie cytaty za wydaniem z 1638.

40 Wzory retoryczne, co do których przykładowego charakteru nie ma wątpliwości, nie będą w niniejszym studium analizowane.

41 Inny przekaz (późniejszy, ale też siedemnastowieczny): Lwowska Narodowa Naukowa Biblioteka Ukrainy im. Wasyla Stefanyka, Biblioteka Baworowskich, f. 4, op. 1/476, k. 193ver.-194rec.

42 Z małżeństwa z Urszulą Dembińską Stanisław miał 4 córki: Barbarę, zamężną za Marcinem Zarembą, starostą grabowieckim, Dorotę, za Janem Tęczyńskim, podczaszym Konstancji Habsburżanki, oraz Annę i Zofię. S. Gruszecki podaje, że 
1607, gdyż w oracji wzmiankowana jest śmierć Stanisława, terminus ante quem wyznacza data śmierci Kryskiego. Tekst mowy znany jest z aż pięciu przekazów, co świadczy o jego popularności, którą jednak przypisać należy nie bohaterce, a osobie mówcy, nazywanego „polskim Demostenesem" 43 .

Laudację podkanclerzanki zacytuję w całości, aby dać pojęcie o pochwale, którą w przypadku szlacheckiej mowy na pogrzebie panny na początku XVII w. można uznać za długą:

I ta zacna córka z obudwu rodziców wielkich i zasłużonych w Koronie familijej czasu swego dojrzała. Ale dojrzała w zacności, w cnotach, w bogobojności, w posłuszeństwie, w niewinności, w cierpliwości, tak że bezchybnie na tę ludzkość W[asz]m[ościów] patrząc, w Bogu prosi go, aby tej chrześciańskiej, którą jej oddawacie, powinności zapłatę błogosławieństwa swego podał $\mathrm{z}$ nieba.

Zwykli ludzie tu dziady malować oracyjami, zbierać pradziady i nadziady swe po kronikach, wspominać rodzice. Mnie tego rozumiem, że nie trzeba przy tym akcie, bo nie w gościnie mówię, nie przed forysterami ${ }^{44}$ rzecz, wspomniawszy ojca Mińskiego, matkę Dębińską, kto z W[asz]m[oś]ciów albo nie czytał, albo nie słuchał, albo się $<$ nie ${ }^{45}$ napatrzył sam godności i zacności tych domów. Co było wielkiego w urzędach, w sławie, w tej Koronie tak w pokoju, jak w zawieruchach, gdzieby pierwszych miejsc ci zacni ludzie nie trzymali? Żal w sercu świeży i jeszcze nieostudzone oczy wspomnieć nie dadzą ojca zmarłe[g]o jej, czł[e]ka nie dni, nie lat, <ale ${ }^{46}$ wieków godnego. Zajźrzeła go zazdrosna Śmierć świat $<\mathrm{u}>{ }^{47}$, zajźrzała jego pobożności i nabożeństwa kościołowi, wiary i szczyrości królowi, zajźrzała rady i powagi senatowi, zajźrzała całości i sławy Ojczyźnie, krewnym uprzejmości, powinnym stateczności, obcym przychylności, wszytkim szczyrej ludzkości ${ }^{48}$.

Kryski podzielił enkomion na dwie części: pierwsza to pochwała indywidualna laudaty, druga to amplifikacja toposu pochodzenia. Klasyczne reguły wymagały, aby enkomion zaczynał się od wspomnienia

Anna pozostała niezamężna, Zofia zaś zmarła we wczesnym dzieciństwie; idem, Miński Stanistaw, PSB, 21, 1976, s. 322. Być może bohaterką oracji jest więc właśnie Anna; zob. też K. Niesiecki, Herbarz polski, t. 6, wyd. J. N. Bobrowicz, Lipsk 1841, s. 4.

43 J. Maciszewski, Kryski Feliks vel Szczesny, PSB, 15, 1970, s. 485.

44 forysterami - cudzoziemcami.

$45<$ nie $>-$ uzup. M.C.

$46<$ ale $>$ - popr. M.C.; do - rkps.

47 świat<u> - popr. M.C.; świata - rkps.

48 Przemowa na pogrzeb Jej M[oś]ci Panny podkanclerzanki, MNK, rkps 187, s. 353. 
przodków zmarłego, czyli zgodnie z chronologią. Tu, choć część pochwały ex genere wkomponowana jest po pochwale panny ex virtutis, orator sygnalizuje obecność tego locus communis we właściwym mu miejscu, czyli już na początku passusu („I ta zacna córka z obudwu rodziców wielkich i zasłużonych w koronie familijej"), co ma świadczyć o celowości tej istotnej zmiany kompozycyjnej i świadomości retorycznej mówcy.

Jak widać, enkomion laudaty ogranicza się do congeries kilku cnót: zacności, czystości, bogobojności, posłuszeństwa, niewinności i cierpliwości. To wierne odzwierciedlenie wzoru osobowego panny szlachcianki, choć przedstawione w sposób wielce oszczędny.

Część drugą otwiera bardzo typowe dla tego okresu praeteritio, które np. w mowach weselnych stanowiło jedynie preludium do rozbudowanej pochwały poszczególnych przodków. W tym przypadku enkomion rodowy ogranicza się do rodziców panny, główny zaś akcent położony został na temat żalu po śmierci podkanclerzego.

Pochwały panieńskie w mowach funeralnych bywały także o wiele krótsze i mniej konkretne. Oto dwa przykłady kompletnych (sic!) enkomionów pochodzących z pierwszej połowy XVII stulecia ${ }^{49}$ :

Nie dziwuj się temu, że szlachetni rodzice płaczą, gdyż utracili z domu swego klejnot, córkę miła, córkę dorosłą, córkę cnotami wszelakimi przyozdobioną, która jako lilija w domu W[asz]m[ościów] kwitnąć, osobliwemi pociechami Was, rodzice, mile karmić poczęła ${ }^{50}$.

Toż w tej zacnej i zmarłej osobie, której dom zacnością familijej, urzędów i dygnitarstwa, dzielnością rycerską ozdobny, dziś, mówię, w tej zacnej kwitnącej osobie dany wieniec baczymy nieśmiertelności. Bo jako wiele sobie przyniosła szczęścia, w wolny[m] i zacnym domu się urodziwszy, jako wiele przodków pociech znacznych dostąpiwszy, nikomu nie tajno, tak na sławę przodków, jako i jej cnoty, i spaniałość młodym wiekiem i wonnością cnót, i postępków uczciwych patrz $<\mathrm{y}>\mathrm{m}<\mathrm{y}>^{51}$. Niewątpliwa, jako jej domowi wiele ozdoby, w cnotach własnych obfitujący ${ }^{52}$, przynosiła, i gdyby nie był dekret Pana nieśmiertelnego, wiele by była przyczynić i rozmnożyć tak pożytków Rzeczypospolitej mogła, niemniej i sławy zacnej familijej swojej. [--] Pewni tego jesteśmy i tym się w tym odeściu

$49 \mathrm{~W}$ niektórych przypadkach usunięto z cytatu wtrącenia o charakterze refleksyjnym lub konsolacyjnym, nienoszące wszakże znamion laudacji.

$50 \mathrm{Na}$ pogrzebie zmartej córki, LVIA, f. 1135, op. 2/40, k. 116rec. Omówienie struktury tej oratorskiej sylwy zob. M. Barłowska, Swada i milczenie, s. 66-81.

${ }^{51}$ patrz<y>m<y> - popr. M.C.; patrzacemu - rkps.

52 obfitujacy - obfitując. 
cieszyć wielce możemy, że się temu Panu wonność cnót jej w młodości kwitnącej upodobała, którym jako w dzieciństwie, jako w potomnym aż do teraźniejszego wieku swego wdzięczny ${ }^{53}$ zapach, śliczną oczom pociechę i niepoślednią domowi ozdobę wydawała ${ }^{54}$.

Powyższe przytoczenia pochodzą z tekstów, które mogły pierwotnie stanowić mowy historyczne (czyli opracowane w związku z rzeczywistymi uroczystościami), zostały jednak przekształcone we wzory retoryczne. O ile w takich przypadkach trudno spodziewać się szczegółowych wywodów genealogicznych, które zazwyczaj usuwano, by uczynić tekst bardziej uniwersalnym, o tyle można oczekiwać wyczerpującej pochwały ex virtutis - uniwersalnej wszak. Jednak nawet taka laudacja, choć opiera się na skończonym i wcale nie bogatym zbiorze, została tu jeszcze bardziej odkonkretniona. W ostatnim przykładzie zmarła jest chwalona ze względu na bliżej nieokreślone „cnoty”, „spaniałość”, „wonność postępków”, a także za bycie „pociechą” i „ozdobą”. Autor wystąpienia powstrzymał się przed choćby prostym nazwaniem tych zalet.

$\mathrm{Na}$ tym tle jako szczególna jawi się laudacja, w której widać szczątkowy zarys życia laudaty:

Żyła na tym świecie w bojaźni Bożej wychowana, w cnotach panieńskich pobożnie wyćwiczona, posłuszeństwem rodziców miłych uweselała, dla układności obyczajów każdemu przyjemną bywała, pokornie, by z najmniejszem, zawsze się obchodziła, nabożeństwem ku Stwórcy swemu często pałała. We wszytkim tak postępowała, jako na stan jej panieński przynależało $^{55}$.

Liczne czasowniki z jednej strony nadają dynamikę, z drugiej zaś tworzą pozór relacji życia zmarłej. Nadal mamy do czynienia z wysokim poziomem ogólności, nadal aktywność panny ogranicza się do przestrzeni prywatnej, nadal żadna z tych czynności nie została poparta żadnym dowodem biograficznym, niemniej jednak laudatę ukazano w realnym świecie.

Kilka szczęśliwie zachowanych mów pozwala rozszerzyć inwentarz godnych pochwały dzieł panieńskich o służbę królowej. Rozpoznane

53 wdzięczny - popr. M.C.; wdzięcznych - rkps.

54 Mowa przy pogrzebie panny, w: Spiżarnia aktów rozmaitych, które się przy zalotach, weselach, bankietach, pogrzebach i tym podobnych inszych zabawach swieckich odprawować zwykty [--], Kraków, 1638, k. F ${ }_{1}$ ver.- $\mathrm{F}_{2}$ rec.

55 Respons potym, LVIA, f. 1135, op. 2/40, k. 144ver. 
dotąd trzy oracje dworskie z pierwszej połowy XVII stulecia o nieustalonych atrybucjach dotyczą bliżej nieznanych panien z fraucymeru Habsburżanek: Konstancji (zm. 1631) lub Cecylii Renaty (zm. 1644). Są to: Dziękowanie na pogrzebie Jej M[ós]ci Panny Wulfianki; Druga na pogrzebie także pokojowej Królowej Jej M[oś]ci ib oraz Mowa na pogrzebie Jej M[ości] Panny Ponętowskiej, pokojowej Królowej Jej M[ó́]ci.

Zaszczyt służby dworskiej jest tak wielki, że przemawiający na pogrzebie Wulfianki odrzuca konieczność amplifikacji zwyczajowych toposów pochwalnych:

Godna tedy jako zalecenia, tak i pochwały ta rzecz, żeście W[asz]m[ości] $\mathrm{m}$ [oi] M[iłościwi] P[aństwo] raczyli przybyć do oddania ostatniej posługi zacnemu tej panienki ciału, którą w młodzieńczym wieku, w nadziejej dalszej śmierć jako kwiat niedojrzały nieubłaganą podcięła kosą. Mnie na tym placu zalecać jej nie potrzeba, dosyć zalecenia stąd ma, że do posług K[rólowej] Jej M[oś]ci na pokój wzięta, gdzie stateczności, skromności, pobożności i innych cnót panieńskich miejsce, ale i to niemniej, co też jest znakiem osobliwej łaski miłe[go] Boga, że też umarła jako umrzeć chrześciańskiemu człowiekowi się godzi, to jest z doskonałym przygotowaniem i sakramentów kościelnych przyjęciem ${ }^{57}$.

Orator przemilcza więc laudację ex genere, choć Wulffowie (lub Wolffowie), herbu własnego, należeli do zasłużonej szlachty ${ }^{58}$, wzmiankuje jedynie osobiste cnoty zmarłej. Są to typowo panieńskie virtutes, które jednak nabierają nowego wymiaru, gdyż definiują sposób, w jaki z laudata wypełniała obowiązki wobec swej pani. Podkreślić też należy wzmiankę o przyjęciu przez konającą sakramentów, co w mowach świeckich nie stanowiło częstego tematu pochwały.

W wyżej cytowanym enkomionie alegoria kwiatu przedwcześnie ściętego przez śmierć ma oczywiście konotacje biblijne, w poniższym

56 Enkomion w tym przekazie został skrócony przez kopistę: „Toż i teraz zwyczajem chrześcijańskim, przy tej ostatniej posłudze uczciwe[go] ciała te[go] przypomnieć się może, że ta zacna białogłowa w takiej kondycyjej i stanie swym panieńskim, tak pobożnie i uczciwie wiek swój odprawiła etc. etc. Zaczym jako K[rólowa] J[ej] M[ość] wiernemi i pilnemi posługami jej zawsze się kontentować raczyła”, Druga na pogrzebie także pokojowej Królowej Jej M[oś]ci, LVIA, f. 1135, op. 2/40, k. $114 \mathrm{rec}$.

57 Dziękowanie na pogrzebie Jej M[oś]ci Panny Wulfianki, LVIA, f. 1135, op. 2/40, k. 114 rec.

58 Wulffowie lub Wolffowie - szlachta z Westfalii, osiadła w Inflantach, Wielkim Księstwie Litewskim i Prusach. Postać laudaty bliżej nieznana; zob. K. Niesiecki, Herbarz polski, t. 9, wyd. J. N. Bobrowicz, Lipsk 1845, s. 396-399. 
przykładzie autor odwołuje się do obrazu fraucymeru królowej przedstawionego jako ogród. Motyw ten będzie obecny w mowach dworskich, także weselnych, przez kolejne dekady:

W tej umarłej panience jaśnie się to pokazać może, że śmierć jej nie tak ma frasować i panią, i ojca, i towarzyszki, aby też i pociechy przynieść nie miała. Jest przyczyna frasunku, że nie dojrzała, że godnych i pięknie zaczętych posług swoich dobrodziejce swej nie kończyła, że towarzyszek swych jako z jednego ogroda wonny kwiat odbiegła, że ojca nie osadziła pożądaną pociechą stołu ${ }^{59}$. Ale że zbyła kłopotów tego świata prędzej, że w łasce paniej i dobrodziejki swej umarła, że w miłości i jedności towarzyszek swych, że w dziewiectwie - próżno się nie cieszyć. Żałosna rzecz umrzeć, ale pięknie, pobożnie, dobrze umrzeć - nie masz czego żałować. Rozbiera to u siebie K[rólowa] J[ej] M[ość] P[ani] n[asza] i teraz, a lubo żałuje ześcia tak zacnej i z ojca, i z matki dziewki, tym się cieszy ${ }^{60}$, że w zupełnych panieńskich cnotach, w doskonałym posłuszeństwie, jeśli nie w dojrzałym wieku, w dojrzałych jednak K[rólowej] J[ej] M[oś]c[i] posługach, roztropności i dogodzie ${ }^{61}$ dni zawarła swoje. A nade wszytko zupełna pociech $<y>^{62}$, zupełna bojaźni Bożej, pełna pobożności, pełna nabożeństwa ducha oddała Bogu. Wiedzieć raczyła K[rólowa] J[ej] M[ość] zacność domu panny Ponętowskiej, kiedy ją do fraucymeru swego przyjmowała, wiedzieć raczyła zawołanie przodków jej i rodowitość, wziętość u ludzi i u przy[jació]t, ale przypatrując się postępkom jej na posłudze swojej, doświadczyć tego raczyła, że dobrej jabłoni, że dobre $<$ go ${ }^{63}$ drzewa dobry owoc który ${ }^{64}$, a to się i samemu Bogu podobało ${ }^{65}$.

W przypadku Ponętowskiej topos pochodzenia pojawia się i to dwukrotnie, jest on jednak w sposób charakterystyczny zredukowany do ogólnych wzmianek, które równie dobrze mogłyby pojawić się we wzorze retorycznym. W efekcie z laudacji ex genere nie sposób ustalić jakichkolwiek faktów genealogicznych ${ }^{66}$. Jedynym punktem

59 ojca nie osadzita pożądana pociecha stotu - prawdopodobny sens: nie osadziła (obsadziła) pożądaną pociechą (tj. swoimi dziećmi) stołu (swojego) ojca.

60 się cieszy - pociesza się.

61 Odczytanie niepewne. Dogoda - dogodzenie, spełnienie.

62 pociech $<y>-$ popr. M.C.; pociecha - rkps.

63 dobre<go> - uzup. M.C.

64 który - nadpisane. Tekst skażony, sens niejasny.

65 Mowa na pogrzebie Jej M<ości> Panny Ponętowskiej, pokojowej Królowej Jej M[oś]ci, LVIA, f. 1135 , op. 2/40, k. 85rec.

66 O rodzinie zob. K. Niesiecki, Herbarz polski, t. 7, wyd. J. N. Bobrowicz, Lipsk 1841, s. 374-375. Niesiecki wzmiankuje dworzanina Kacpra Ponętowskiego i Piotra, sekretarza królewskiego, nic nie wskazuje jednak na to, aby laudata miała być spokrewniona z którymś z nich. 
odniesienia jest królowa: jej wiedza o zacności rodziców dwórki i o szacunku oraz „wziętości u ludzi” czyni ród zmarłej jeszcze świetniejszym, jej doświadczenie godnego zachowania się laudaty potwierdza znakomitość jej rodziców. Należy też podkreślić, że to królowa boleje nad śmiercią młodej szlachcianki i pociesza się pewnością jej zbawienia. Charakterystycznym dla mów dworskich jest przesunięcie roli, zazwyczaj ${ }^{67}$ odgrywanej przez rodziców jako żałobników i opiekunów, ale także organizatorów pogrzebu, właśnie na osobę władczyni. To w jej imieniu występuje orator, w jej imieniu dziękuje zebranym gościom za przybycie, w jej imieniu na końcu składa im życzenia i deklaruje łaskę ${ }^{68}$. Ta zmiana kompozycyjna odwzorowywała realia, gdyż monarchini stawała się faktyczną opiekunką swoich dwórek.

Ostatnia mowa świecka pochodzi z drugiej połowy wieku XVII. Trzydzieści lat w historii oratorstwa to niemal cała epoka, gdyż wygłoszone około 1660 r. $^{69}$ przemówienie kniazia Marcjana Aleksandra

67 Podobny mechanizm dostrzegamy w mowach wygłaszanych na weselach dwórek; zob. M. Trębska, Staropolskie szlacheckie oracje weselne, s. 346-357.

68 „Co też K[rólowa] J[ej] M[oś]ć w tej stracie życzliwej sługi swej cieszy się, cieszy i z te[go], żeście W[asz]m[oście] do ostatnie[go] te[g]o aktu przybyć, jako powinność chrześcijańska, tak też i chęć przeciwko K[rólowej] Jej M[ości] oświadczyć i onę w usłudze jej uczcić raczyli. Przystojną wdzięcznością przyjmować to raczy J[ej] K[rólewska] $\mathrm{M}$ [o]ść, do pocieszniejszych sobie okazyj życząc, w których by łaskę swoję i życzliwość oświadczyć mogła. Którą przez mię natenczas W[asz]m[oś]ciom raczy ofiarować”, Dziękowanie na pogrzebie Jej M[oś]ci Panny Wulfianki, k. 114rec.; „[królowej] taż śmierć jej żałosną zostawszy, wdzięcznie to od W[asz]m[oś]ciów przyjmować raczy, że nie tylko pomagacie żalu te[go] K[rólowej] J[ej] M[o]ści, ale i uczciwość tę zmarłej tak miłej słudze oddawać raczycie. Gotowa będąc K[rólowa] J[ej] M[oś]ć łaską swą oświadczenie chęci W[asz]m[oś]ciom ku sobie w pocieszniejszych okazyjach nagradzać”, Druga na pogrzebie także pokojowej Królowej Jej M[ó́]ci, k. 114rec.; „W[asz]m[oś]ciom zasię m[oim] M[iłościwym] P[anom] senatorom J[ego] K[rólewskiej] M[ości] i wszystkiemu dworowi, którzyście czyli [sic!] powolność swoję $\mathrm{J}$ [ej] K[rólewskiej] M[ości] przy tym akcie, posługę sobie w tej mierze uczynioną, $\mathrm{K}$ [rólowa] J[ej] M[ość] P[ani] n[asza] M[iłościwa] łaską swą pańską oddawać nie zaniecha. Wdzięcznością swą nagradzać chce, żeście nie tylko w pociesznych, ale i w tych, co z sobą przynoszą frasunki, gotowi być przy paniej i dobrodziejce swej. Pobożność chrześcijańską, wierzę, że Bóg, który na nię patrzy z nieba, bez chyby nagrodzi”, Mowa na pogrzebie Jej M<ości> Panny Ponętowskiej, pokojowej Królowej Jej M[oś]ci, k. 85rec. (tekst bardzo skażony, zrekonstruowany na podstawie marginaliów).

69 Mowa tegoż J[ego] M[ości] Pana w[ojewo]dy trockiego na pogrzebie Jej M[ości] Pani trockiej i córki oraz, Sapieżanki, pisarzowej W[ielkieg]o Ks[ięstw]a Lit[ewskieg]o, MNK, rkps 425 III, s. 277-279. Data pogrzebu ustalona na podstawie daty 
Ogińskiego (1632-1690), wówczas podstolego wielkiego litewskiego, na pogrzebie Anny Sapieżanki, byłej dwórki Ludwiki Mariii ${ }^{70}$, córki Mikołaja Krzysztofa (zm. 1639), pisarza polnego litewskiego i starosty wilkijskiego, oraz Zuzanny z Gosiewskich 1. voto Sapieżyny, 2. voto Wilczkowej (zm. 1660), nosi znamiona zachodzących zmian.

Mowa ta została wygłoszona na podwójnym pogrzebie matki i córki, o czym informuje zarówno tytuł, jak i fragment tekstu. O samej Zuzannie Sapieżynie-Wilczkowej orator zaledwie wspomina w kontekście pochwały Anny ex genere, co może oznaczać, że scenariusz pogrzebowy przewidywał dwa dziękowania: w jednym chwalono matkę, w drugim córkę. Mimo że panna była we fraucymerze Ludwiki Marii, w mowie gościom za przybycie i przedmówcom za wystąpienia dziękuje się w imieniu rodziny, nie zaś królowej. Podziękowania Ogiński kieruje też do posła królewskiego jako pierwszego, co oznacza, że to nie dwór monarszy organizował ów pogrzeb.

Enkomion Sapieżanki jest nieporównanie obszerniejszy niż dotychczas tu przedstawiane. Otwierają go kunsztowne, alegoryczne przedstawienia mobiliów w herbie panny (strzały w herbie Lis) jako metonimii rodu Sapiehów ${ }^{71}$. Kolejno następuje pochwała ojca zmarłej, a po niej - matki, obie jednak w kontekście tradycji rodowej ${ }^{72}$. Po rodzicach laudaty Ogiński sławi jej babki: ojczystą z Hołowczyńskich

śmierci Zuzanny z Gosiewskich Sapieżyny-Wilczkowej (1660). O ponownym ślubie Zuzanny z Janem Anzelmem Wilczkiem, kasztelanem trockim zob. K. Niesiecki, op. cit., t. 9, s. 331; A. Rachuba, Mikotaj Krzysztof, w: Dom Sapieżyński, t. 1, oprac. E. Sapieha, Warszawa 1995, s. 336. Brak tej informacji u Dworzaczka; Genealogia [2]. Tablice, oprac. W. Dworzaczek, Warszawa 1959, tabl. 179.

70 „W kontrakty małżeńskie [Mikołaj Krzysztof Sapieha] wszedł z Zofią lub z Zuzanną Korwinówną Gosiewską, wojewodzianką smoleńską, a córki z niej z różnymi spowinowacił domami [--]. Anna zaś w panieńskim stanie w fraucymerze królowej Ludwiki zmarła”, K. Niesiecki, Herbarz polski, t. 8, wyd. J. N. Bobrowicz, Lipsk 1841, s. 258. Dworzaczek nie zna żadnej córki tej pary; Genealogia, tabl. 179.

71 Krótki fragment tego przedstawienia: „I ta to jest beatitudo, której sama ta sapieżyńska strzała, żeleźcem swoim ad instar kotwicy dwiema krzyżami amoris patriae et fidei ugruntowana, nie już doczesnego życia, ale wiecznego nieomyloną czyni nam nadzieje”, Mowa tegoż J[ego] M[ości] Pana w[ojewo]dy trockiego, s. 278.

72 „Nie dość jej było urodzić się z tak wysokich domów, z ojca Krzysztofa Sapiehy, z owego Herkulesa ojczyzny naszej syna, o którym to było wspomnienie, iż wysokie dzieła onego multorum suffragiis stołku senatorskiego na tron królewski promowaniu post decessu[m] króla Augusta godnym być sądzili; z matki Gosiewskiej, z owych Korwinów rzymskich jeszcze idący, tym szczęśliwszej, im ad aeternitatem pennis corvi herbu swego zaniesiona, temiż i tę strzałę córy, etiam in funere amore iuncta, ad astra wynosi", ibidem, s. 278. 
i macierzystą z Paców, oczywiście ex genere, pamiętając o wkomponowaniu w poszczególne laudacyjne cząstki zgrabnych metafor heraldycznych, po czym przechodzi do enkomionu indywidualnego panny, który stanowi trzecią część całej pochwały:

Nie dość było honoris przy tym, iż ze wszytkiemi innemi przedniejszemi, które jeno tak Korona Polska, jak W[ielkie] Ks[ięstwo] L[itewskie] liczyć może, spowinowacić się domami, ale aby w tak zacnym gnieździe spłodzona, $\mathrm{w}<\mathrm{t}>$ akowych ${ }^{73}$ ozdobach domu swego wychowana, cnót też korespondujących, którebymi nieba sięgać mogła, dziedziczką zostawała, na to wszytkie życia swego obracała conatus. W czym wyćwiczona, osierociała zaraz po matce zostawszy ${ }^{74}$, oddana do usług Królestwa Ich M[ości], w pobożności ku Bogu, w miłości ku Ojczyźnie, szczerożyczliwości ku państwu, w posłuszeństwie ku opiekunom swym jako rodzicom, w uszanowaniu ku starszym, w dobroci ku swoim, w skłonności ku wszytkiemu żyjąc, wielu i dworu kawalerów znacznych na się obracała oczy. Ale kwiatka tak pięknej woni zajrzało ziemi Niebo, który upodobany Niebieskiemu Oblubieńcowi, lubo na początku kwiatu zerwany, non exaruit [--]. I ta to jest tej cnej damy pamiątka, która sama mityguje nie tylko dom Sapieżyński w żalu z straty tak pięknej ozdoby, ale oraz i nas, wszytkich krewnych ${ }^{75}$.

Ogiński chwali zmarłą ze względu na wszystkie cnoty panieńskie zwyczajowo przypisywane jej stanowi, ale dodaje jeszcze dwie, których nie uwzględniono we wcześniej przedstawionych oracjach: miłość do Ojczyzny i „szczerożyczliwość ku państwu”, tzn. do pary królewskiej. O ile virtus wymieniona jako następna, posłuszeństwo opiekunom (tj. królowi i królowej), jest tylko drobnym przeformułowaniem jednej z podstawowych cnót, o tyle te dwie wynoszą Sapieżankę ponad krąg spraw rodzinnych. Ogiński, przyznając pannie prawo do uczuć patriotycznych, uczynił ją świadomą uczestniczką znacznie szerszej wspólnoty - narodowej.

Ideał panny ukazany w enkomionach funeralnych mów szlacheckich w niewielkim tylko stopniu odbiegał pod względem wzmiankowanych cnót, jakimi winna być obdarzona laudata, od wzorów osobowych przedstawianych w kazaniach. Zarówno mówca świecki, jak i kaznodzieja podejmowali tematy tych samych mniej więcej virtutes, zidentyfikowanych już przez badaczki w dotychczasowych analizach.

$73<t>$ akowych - popr. M.C.; jakowych - rkps.

74 Fragment niejasny. Być może Anna została oddana do fraucymeru królowej między śmiercią matki a jej pogrzebem z jakiś powodów odsuniętym w czasie.

75 Mowa tegoż J[ego] M[ósici] Pana w[ojewo]dy trockiego, s. 278-279. 
Wśród cnót panieńskich „wydestylowanych” z treści kazań pogrzebowych (poświęconych głównie matronom) ${ }^{76}$ Urszula Kicińska wskazała: skromność, małomówność, powściągliwość, pokorę, pobożność, cierpliwość, wstydliwość, wdzięczność, przystojność obyczajów, czystość czy posłuszeństwo ${ }^{77}$, co $\mathrm{w}$ zasadzie pokrywa się z przedstawionymi tutaj wynikami analiz. Ponieważ jednak do tej pory nie prowadzono rozpoznań o charakterze porównawczym uwadze umykał fakt zasadniczych różnic w sposobie przedstawienia tych samych treści.

Kazania funeralne $\mathrm{w}$ przeciwieństwie do mów szlacheckich były chętnie wydawane $\mathrm{w}$ postaci druków okolicznościowych, mimo to publikacji tego typu poświęconych pannom szlachciankom zachowało się z XVII w. zaledwie dziewięć c $^{78}$ :

1. 1606 r. - Jana Turnowskiego na pogrzebie Anny Krotoskiej, córki Andrzeja, wojewodzica inowrocławskiego ${ }^{79}$;

2. 1625 r. - Tomasza Węgierskiego na pogrzebie Aleksandry Leszczyńskiej, córki Rafała, wojewody bełskiego ${ }^{80}$;

76 Oratorzy, zarówno świeccy, jak i kościelni, chwalili zmarłe ze względu na cnoty przypisane kolejnym etapom życia kobiety: panny, mężatki i matki oraz wdowy. Dlatego wzmianki o cnotach panieńskich znajdują się także w laudacjach nawet leciwych niewiast, np. „Ktokolwiek ją bowiem znał albo o niej słyszał, przyznać jej musi w stanie panieńskim wstyd niewinności pełny, w małżeńskim przystojność wszelaką i statek nienaganiony, w wdowiem świątobliwość rzadką", J. Sobieski, XIV. Dziękowanie na pogrzebie Anny Eufrozyny Sieniawskiej z Chodkiewiczów, chorażyny wielkiej koronnej, w: idem, Mowy pogrzebowe, s. 91 (XVI, 12).

77 U. Kicińska, Wzorzec szlachcianki, s. 263-267.

78 W spisie tym nie znalazło się kazanie Wojciecha Pigłowskiego na pogrzebie Konstancji Czarnkowskiej, które między innymi „panieńskimi” wskazała U. Kicińska (idem, Wzorzec szlachcianki, s. 253-254, przyp. 83), gdyż laudata w chwili śmierci była już mężatką. Por. np. „Mówię bezpiecznie, jako żyjąc na świecie, tak i teraz ta świątobliwa matrona była i jest torrens inundans gloriam, strumieniem pochwały, a to z urodzenia i wychowania, z panieńskiej i małżeńskiej przystojności, z pobożności i śmierci chrześcijańskiej”, W. Pigłowski, Rzeka pokoju i strumień powódź stawy niosący, to jest: Kazanie na pogrzebie Wielmożnej Jej Mości Paniej Konstancyjej z Lubomirza Czarnkowskiej, międzyrzeckiej, pyzdrskiej, etc. starościnej, miane w kościele czarnkowskim przez Ks[iędza] Wojciecha Pigtowskiego, kanonika poznańskiego, wateckiego proboszcza, I. Octobr. 1646, Poznań 1646, k. $\mathrm{B}_{3}$.

79 J. Turnowski, Pogrzebne stowa wyrzeczone nad zacnym ciatem J. M. Panny Anny z Krotoszyna Krotoskiej, etc. [--], roku Naświętsz. Pana N. (I) I) (VI dnia 4 maja, Gdańsk 1606; por. K. Estreicher, Bibliografia polska, t. 1-34, Kraków 1870-2000, tu t. 31, s. 405; M. Skwara, Polskie drukowane oracje pogrzebowe, nr 509.

80 T. Węgierski, Kazanie pogrzebne, sposób chrześcijańskiej żatoby i w niej przedniejsze z pism śs. pociechy wyrażające, nad zacnym ciatem st. pamięci J.W.P. Jej Mści Panny Aleksandry hrabianki z Leszna Leszczyńskiej, wojewodzanki betskiej, etc. 
3. 1648 r. - Jacka Sierakowskiego na egzekwiach Marianny Berżewiczówny, córki Jana ${ }^{81}$;

4. 1649 r. - Aleksandra od Jezusa (Andrzeja Kochanowskiego) na pogrzebie Barbary Lanckorońskiej, córki Stanisława, kasztelana kamienieckiego ${ }^{82}$;

5. 1651 r. - Eleuterego Zielejewicza na pogrzebie matki i córki: Anny Towiańskiej, sędziny wiłkomirskiej, i Reginy Towiańskiej, sędzianki wiłkomirskiej ${ }^{83}$;

6. 1652 r. - Aleksego Piotrkowczyka na pogrzebie: Elżbiety z Szemetów Pacowej, wojewodziny trockiej, Anny z Zawiszów Pacowej i zmarłej w niemowlęctwie Krystyny Pacówny - matki, żony i córki Feliksa Jana, podkomorzego wielkiego litewskiego ${ }^{84}$;

etc., we Wtodawie [--] XVII dnia maja roku Pańskiego MDCXXIV odprawione [--], Lubcz 1625; por. K. Estreicher, op. cit., t. 32, s. 292; M. Skwara, Polskie drukowane oracje pogrzebowe, nr 525.

81 J. Sierakowski, Prezenta wielocnót przezacnego domu Berżewiców i Jaśnie Urodzonej Panny Jej Mci Panny Marianny Berżewicewnej w Księstwie Pruskim na Lisnowie za żywota, nadzieja, że $i$ po śmierci $w$ Niebieskim Indygenacie pewnej dziedziczki, w kościele lisnowskim przy pogrzebowym akcie, na wtórych obsekwiach siódmego dnia października roku Pańskiego 1648 [--], Toruń b.d.; por. K. Estreicher, op. cit., t. 32, s. 58; M. Skwara, Polskie drukowane oracje pogrzebowe, nr 463.

82 Aleksander à Jesu (A. Kochanowski), Plastr miodu od śmierci pożarty, ale śmierci wydarty, to jest kazanie na pogrzebie Jej Mci Panny Barbary Lanckorońskiej, kasztelanki kamienieckiej, Jaśnie Wielmożnego Jego Mci P. Stanistawa z Brzezia Lanckorońskiego, wojewody bractawskiego [--], kochanej córki miane [--] die 23. Novembris, anno 1649. Do druku podane za dozwoleniem Starszych, [Kraków 1649]; zob. K. Estreicher, op. cit., t. 19, s. 356; M. Skwara, Polskie drukowane oracje pogrzebowe, nr 92. O kazaniu tym wzmianki w: U. Kicińska, Wzorzec szlachcianki, s. 27, 265; A. Nowicka-Struska, op. cit., s. 59-60.

83 E. Zielejewicz, Kazanie umartych do żywych, które miaty kości zmartych w Chrystusie Jej Mości Paniej Anny Szczytówny Zabielskiej, Kasprowej Towiańskiej, sędzinej witkomirskiej, grodzkiej, i Jej Mości Panny Reiny Towiańskiej, sędzianki witkomirskiej oraz, w kościele witkomirskim die 24. [Octo]bris anno 1651 grzebionych [--], Vilnae [1651]; por. K. Estreicher, op. cit., t. 8, s. 281; M. Skwara, Polskie drukowane oracje pogrzebowe, nr 565.

84 A. Piotrkowczyk, Zawitanie trzech osób: Jaśnie Wielmożnej Jej Mości Paniej Elżbiety Szemetówny Pacowej, wojewodzinej trockiej [--], Wielmożnej Jej Mości Paniej Anny Konstancyjej Zawiszanki, podkomorzynej W.KS.L. [--], Wielmożnej Jej Mości Paniej Krystyny Pacówny, podkomorzanki W.Ks.L. do grobu chwalebne, [--] $z$ ambony wileńskiej roku P. 1652. dnia 15 Octobra kazaniem ogtoszone, [Wilno 1652]; por. K. Estreicher, op. cit., t. 24, s. 296; M. Skwara, Polskie drukowane oracje pogrzebowe, nr 386. Krótkie wzmianki o tym kazaniu w: U. Kicińska, Wzorzec szlachcianki, s. 52. 
7. 1662 r. - Mateusza Lisickiego na pogrzebie ojca i dwu córek: Jana Szołdrskiego, cześnika ziemskiego kaliskiego, Barbary i Jadwigi ${ }^{85}$;

8. 1675 r. - Rajmunda Piegłowskiego na pogrzebie trojga dzieci Stefana Światopełka Czetwertyńskiego, chorążego wołyńskiego: Włodzimierza, starosty siewińskiego, oraz jego sióstr - Teresy i Krystyny, chorążanek wołyńskich ${ }^{86}$;

9. 1698 r. - Aleksandra Elisza na pogrzebie Zofii Engracji Hulewiczówny, córki Stanisława, wojskiego włodzimierskiego i sędziego grodzkiego łuckiego ${ }^{87}$.

Kazanie Jana Turnowskiego z roku 1606, wygłoszone na pogrzebie liczącej około 9 lat Anny Krotoskiej ${ }^{88}$, młodszej siostry zmarłego wcześniej Jana i córki seniora Jednoty Braci Czeskich, w ogóle nie ma części pochwalnej. Kazania ewangelickie (luterańskie, kalwinistyczne, czesko-braterskie etc.) nie zawierały enkomionów osób zmarłych, zamiast tego ich twórcy na końcu druku dołączali biogramy, tzw. Personalia ${ }^{89}$. W tym przypadku po treści kazania następują jedy-

85 M. Lisicki, Eódź do szczéśliwego portu ptynąca, przy pogrzebinach Jego Mości Pana, P. Jana Szotdrskiego, cześnika ziemskiego kaliskiego, także Ich Mościów Panien Barbary i Jadwigi, dwu cór Jego Mości, Szotdrskich, kazaniem żatobnym [--] w kościele czempińskim dnia 11. grudnia, w roku Pańskim 1662. [--] wyprawiona, Poznań [1633]; por. K. Estreicher, op. cit., t. 21, s. 331; M. Skwara, Polskie drukowane oracje pogrzebowe, nr 279. O kazaniu tym wzmianki w: U. Kicińska, Wzorzec szlachcianki, s. 202, 243, 266; M. Skwara, O dowodzeniu retorycznym $w$ polskich drukowanych oracjach pogrzebowych XVII wieku, Szczecin 1999, s. 335.

86 R. Piegłowski, Pokój i nieśmiertelność Jaśnie Oświeconego Wtodzimierza Swatopetka, Książęcia Czetwertyńskiego, starosty siewińskiego, i rodzonych jego: Teresy i Krystyny, chorażanek wotyńskich, na jednym katafalku [--] wystawionych [--], Kraków 1675; por. K. Estreicher, op. cit., t. 24, s. 246; M. Skwara, Polskie drukowane oracje pogrzebowe, nr 373.

87 A. Elisz, Góry ukoronowane Jej Mść Pannę Zofija Engracyja Hulewiczównę, sędziankę tucka, na wesele niebieskie wynoszace, przy ziemskich z jej odeścia żalach pogrzebowym kazaniem ogtoszone $w$ kościele tuckim Societatis Jesu nazajutrz po święcie nawiedzenia Najświętszej Panny, roku z Gór Niebieskich zniżonego Boga 1698 [--], Lwów [1698]; por. K. Estreicher, op. cit., t. 16, s. 48; M. Skwara, Polskie drukowane oracje pogrzebowe, nr 177.

${ }^{88}$ Brak informacji o tej postaci; zob. J. Dworzaczkowa, Krotoski (Krotowski) Jan h. Leszczyc, PSB, 15, 1970, s. 344-345.

89 M. Skwara, Polskie drukowane oracje pogrzebowe, s. 46. Taki biogram ze wszelkimi detalami opisującymi zachowanie i postawę moralną w śmiertelnej chorobie dwunastoletniej Anny Dębowskiej, córki wileńskiego aptekarza, w: A. Schoenflissius, Córa Jairowa zmarta, od Chrystusa wzbudzona, na pogrzebie cnej i pobożnej Panny Anny Dębowskiej, szlachetnego Pana Marcina Dębowskiego, aptekarza 
nie utwory epitafijne, za to na samym początku pojawiają się w kontekście lamentacyjnym wzmianki o dziecku „zacnego domu wielkiej familijej”, które cieszyło rodziców „wdzięcznością udatną, wzrostu spaniałością, zdrowia czerstwością”, a nawet „śliczną twarzą"90. Analogicznie osobny utwór panegiryczny zastąpił enkomion w treści kazania Tomasza Węgierskiego ${ }^{91}$ poświęconego Aleksandrze Leszczyńskiej, córki przywódcy polskich innowierców ${ }^{92}$, w roku 1625.

Dopiero Prezenta wielocnót dominikanina Jacka Sierkowskiego z 1648 r. przynosi widoczną zmianę. Stopień nasycenia tekstu poświęconego Mariannie Berżewiczównie panegiryzmem jest nieporównany z niczym, co było tu do tej pory przedstawiane. Passusy pochwalne są tak liczne i obszerne (sam enkomion dziada i ojca Marianny liczy kilka stron druku), że z konieczności przedstawię jedynie drobne wyjątki. W pierwszej części mówca bardzo szczegółowo przedstawia rodowód laudaty, historię indygenatu nadanego Marcinowi Berżewiczowi sprowadzonemu z Węgier przez Batorego, liczne koligacje z Kryskimi, Czerskimi etc., oraz sam herb (Berżewicz), w którym widnieją: orzeł, kozioł w biegu, półlew, księżyc z gwiazdą i półpierścień z półstrzałą ${ }^{93}$. To ostatnie zainspirowało kaznodzieję do nadania zmarłej pieszczotliwych imion ,jedynego orlęcia”, „kochanego lwięcia” czy „miłego koźlątka"94. Mobilia stanowią też źródła heraldycznych metafor i rozbudowanych konceptów, które organizują obszerne części tekstu $^{95}$. Postać młodej Berżewiczówny zostaje przeniesiona w przestrzeń symboliczną, w której pod postacią orlęcia czy kózki działa i ma moc sprawczą. Oto kilka zaledwie bardzo krótkich cytatów:

Orzeł [tj. Jan, ojciec zmarłej] przezacnego domu Ich M[ości] m[oich] M[iłościwych] P[anów] Berżewiców [--] kochane gniazda swego orlęta,

$i$ mieszczanina wileńskiego, najmilszej $i$ jedynej córki wystawiona w Wilnie, na cmintarzu [sic!] saskim roku Pańskiego, 1635. 4. maja. [--], b.m. 1635. Kazanie to nie jest tu analizowane ze względu na jego mieszczańską proweniencję.

90 J. Turnowski, Pogrzebne stowa, k. A, rec.

91 T. Węgierski, Kazanie pogrzebne, k. Iver.-I_ver.

92 Brak informacji o zmarłej w biogramie ojca; zob. M. Sipayłło, Leszczyński Rafat h. Wieniawa, PSB, 17, 1972, s. 135-139.

93 Zob. rycina na recto karty tytułowej druku; K. Niesiecki, Herbarz polski, t. 2, wyd. J. N. Bobrowicz, Lipsk 1839, s. 110.

94 J. Sierakowski, Prezenta wielocnót, k. A rec.-ver.

95 Części: Prezenta cnót je [sic!] przy orła biatego przymiotach (od k. B 3 ver.), Prezenta cnót z wtasności kózki (od k. Drec.), Prezenta lwa z muru z prawda oraz i pótpierścienia z pótstrzatą (od k. Erec.). 
a osobliwie to w oczach naszych orlę, Jej Mość Pannę Maryjannę Berżewicewnę, w wierze ś[więtej] z legitimo thoro spłodziwszy, onej trybem orła wychowanie prowidował. Sama ją Cnota i urodzenie pańskie, niewinności wytuczone [sic!] obyczaje swych piersi białością karmiła. Sama ją pańska Sława rękoma własnemi piastowała, a tak piastowała, żeby i polskie, i inne postronne państwa nic innego w tym orlęciu nie zoczęły, jedno co cnót orlęcych, cnót pańskich, co Niebu i ziemi wdzięcznego było ${ }^{96}$. [--]

I ta przezacna kózka, Jej M[ość] Panna Maryjanna, w rączym biegu w cnotach pobożnych stronieła od złych obyczajów i postępków, lecz tropami prostemi chrześciańskiemi rączość miłości osobliwej do Stwórce i Zbawiciela swego zmierzała. [--] i ta kózka, Jej M[o]ść Panna Berżewicewna, bieżąc do onego klarownego, niebieskiego źrzódła Chrystusa Pana, nie dbała o pozór światowy, o kwiecie pięknej urody swojej, o światowe ornamenta $^{97} \cdot[--]$

Nie ustąpiła z tych tropów Jej Mość Panna Maryjanna, siostrzanka Twoja ${ }^{98}$, ale jako strzała pochopem miłości Bożej, świętymi sakramentami napuszczona bieży ad astra, między one gwiazdy niebieskie, wiecznie świecące. [--] Dziś to orlę wyświadcza ultimum ardorum, gorącą miłość ku Słońcu sprawiedliwemu, Chrystusowi Panu. Dziś ta jutrzenka dobrą noc wszytkim powiada, swój bieg zwodząc w one niebieskie dni wieczne. Dziś ta kózka na onę wysoką, wesoło wieczną górę syjońską poskoczyć usiłuje. Dziś to lwiątko u tronu Boskiego stanąć szczęśliwie pragnie. Dziś ta panienka pierścieniem zrękowiny ma brać w Niebie z Oblubieńcem wiecznym ${ }^{99}$.

Wszystkie te działania w fantastycznym świecie symboli heraldycznych można oczywiście sprowadzić do tematu cnót pobożności, posłuszeństwa czy niewinności, ale takie przedstawienie powoduje, że panna nie jest chwalona ex virtutis, ale ex merita (za czyny, dokonania, zasługi), nawet jeśli większość z nich, poza uczestnictwem we mszach świętych i przyjmowaniem sakramentów ${ }^{100}$, pozostaje w sferze ornamentacji retorycznej i konceptu heraldycznego.

Sierakowski dokonuje jeszcze jednego ciekawego zabiegu: przenosi na zmarłą z jej matki zasługę rzeczywistych aktów miłosierdzia i dobroczynności:

[Marianna jako białe orlę] rozrzuca rękoma rodzicielkiej swej, w łasce Bożej żyjącej, to bibliotekę po Ich M[ościach] P[anach] Berżewicach zostawioną, na kilka tysięcy w księgach szacowaną do klasztoru lubawskiego,

\footnotetext{
96 J. Sierakowski, Prezenta wielocnót, k. $\mathrm{C}_{3}$ ver.

97 Ibidem, k. D 4 rec.

98 Apostrofa do Olbrychta Czerskiego, kasztelana chełmskiego, wuja zmarłej.

99 Ibidem, k. E Ever. $^{2}$

100 U. Kicińska, Wzorzec szlachcianki, s. 289 (tab. 1, poz. 2).
} 
to kosztowne klejnoty na cudowny obraz Panny Naśw[iętszej] do Skąpego $^{101}$, to bławatne szaty na aparaty kapłańskie do klasztoru świeckiego ojców bernardynów, to inne drobniejsze na okrycie sierot nagich szaty ${ }^{102}$.

W oracjach szlacheckich takie merita określane są krótko i ogólnikowo jako „hojne jałmużny”; niezwykle zaś rzadko, jeśli w ogóle, je wyliczano. Tu ujawnia się zasadnicza różnica wynikająca ze statusu mówcy: kaznodzieja, duchowny, ma wskazywać wiernym wzorce (również hojności) do naśladowania, a także występuje jako przedstawiciel beneficjentów, jest więc zobowiązany do obszernych, często znacznie dokładniejszych niż w cytowanym fragmencie, opisów darów. W tym przypadku wdzięczność i pochwała przypadają córce, nie matce, co jest możliwe w planie symbolicznym, niekoniecznie zaś w bliskiej światu rzeczywistemu mowie szlacheckiej.

Równie ciekawe jest kazanie wygłoszone przez Mateusza Lisickiego w 1662 r. na potrójnym pogrzebie Jana Szołdrskiego herbu Łodzia, cześnika kaliskiego, i jego dwu córeczek: Barbary i Jadwigi ${ }^{103}$. W mowach upamiętniających kilka osób ze sobą spokrewnionych pochwała ze względu na pochodzenie ojca lub matki jest również pochwałą ex genere córki czy syna, natomiast laudacja ex meritis $\mathrm{w}$ enkomionie indywidualnym rodzica przesuwa się do kategorii laudacji ex genere dziecka. Tak też jest w tym kazaniu. W Łodzi do szcześliwego portu ptynacej, prócz wywodu genealogicznego zmarłego cześnika i zalecenia go ze względu na dokonania i cnoty ${ }^{104}$, mówca zawarł też bardzo interesującą pochwałę jego wcześniej zmarłej siostry. Ta enkomiastyczna cząstka, szczególnie na tle enumeracyjnego charakteru szlacheckich pochwał ex virtutis ${ }^{105}$, zwraca uwagę konkretem biograficznym:

A któżby się był spodział w onej łódce subtelnego, bo postami, a prawie niepodobnymi $\mathrm{w}$ takiej ułomności mortyfikacyjami wysuszonego

101 Klasztor bernardynów w Skępem.

102 J. Sierakowski, Prezenta wielocnót, k. Drec. O tej fundacji jako przekazanej przez pannę por. U. Kicińska, Wzorzec szlachcianki, s. 310.

$103 \mathrm{O}$ rodzinie zob. K. Niesiecki, op. cit., t. 8, s. 623-627. Brak informacji o Barbarze i Jadwidze.

104 M. Lisicki, Łódź do szczęśliwego portu ptynąca, k. Crec.-ver.

105 Por. w mowie szlacheckiej: „Świecą przed oblicznością Pańską świątobliwe uczynki jej, one gorące modlitwy, one bogate fundacyje, one hojne jałmużny, one surowe umartwienia; świecą i wszelkim stanom tu, na ziemi, i równe z tym słońcem świecić będą wielkich cnót nie mniejsze przykłady”, J. Sobieski, VIII. Dziękowanie na pogrzebie Anny Ostrogskiej z Kostków, w: idem, Mowy pogrzebowe, s. 104 (VIII, 40). 
i wymizerowanego ciała Jej M[o]ści Pannej Anny Szołdrskiej, rodzonej niegdy tegoż Jego Mości Pana cześnika zmarłego, tak wiele naładowanych towarów pobożnościej [sic!], pokory, bogomyślności i doskonałości [--]. W kościele dni całe na modlitwie trawiąc, a przy postach takich, że przez lat około trzydzieści bez mięsnych i mlecznych potraw, w cudownej życie swoje prowadziła surowości ${ }^{106}$.

Kazanie to podporządkowane jest organizującemu je całościowo konceptowi heraldycznemu, jednak mówca ukazał cześnikówny również $\mathrm{w}$ planie historycznym:

Nie takie były zacne córy Jego Mości Pana cześnika naszego, gdyż dni życia ich nie na próżnowaniu (a mówię to, czegom był oczywistym świadkiem), ale na poczciwych zabawkach szlacheckich, na ćwiczeniu w doskonałościach panieńskich. Nie przeszkodziły tym pobożnym pannom żadne niepogody, nic deszcze, nic niesposobność drogiej do kościoła, na każdy dzień mszej świętej słuchać. Z kościoła przyszedszy, zaraz do krosienek, każda do swojej sobie osobnie skrzyneczki szyła. Nuż, kiedy tego potrzebowały czasy, i do kądziołki, gdzie zaprawdę nie uwłókło to włókno nic honorowi szlacheckiemu, nic stanowi panieńskiemu. Owo zgoła, gaudebat pater et mater de operibus illarum, mieli kochani rodzicy z tych dziatek swoich mnogie korzyści pociech, patrząc na pożądany skutek poczciwego w dziatkach swoich wychowania ${ }^{107}$.

Zarówno Anna, jak i obie jej bratanice przedstawione są w ich rutynie, $\mathrm{w}$ codziennych umartwieniach, aktach pobożności czy pracy odpowiadającej szlacheckiemu modelowi wychowania dziewcząt. Jest to więc dość szczegółowy opis faktycznego działania pełniący funkcję argumentu pochwały ${ }^{108}$. Nie oznacza to bynajmniej, że Lisicki zrezygnował z chwalenia "dokonań" pozostających w planie symbolicznym. Kaznodzieja przytacza m.in. egzemplum o synu, który przetrwał katastrofę morską, trzymając się unoszonego przez fale trupa swego ojca, do którego to przykładu dodaje następujący komentarz aktualizujący kontekst:

Nie wypłynęły-ć te zacne córy, Jej Mość Panna Barbara i Jadwiga Szołdrskie, z tych nurtów śmiertelności, nie! Ale trunny swoje oto przy bokach ojcowskich na tym żałosnym katafalku położywszy, z trupem ojca swojego wolały zatonąć, aniżeli w wierze dziecięcej ku ojcu jaki uszczerbek popaść. Quomodo in vita sua dilexerunt se, ita et in morte non sunt separati, jako

106 M. Lisicki, Eódź do szczęśliwego portu ptynąca, k. $\mathrm{C}_{2}$ rec.

107 Ibidem, k. F 3 rec.-ver.

${ }^{108}$ U. Kicińska (eadem, Wzorzec szlachcianki, s. 292, tab. 1, poz. 72-73) wymienia: udział we mszach świętych, przyjmowanie sakramentów i modlitwę. 
w życiu swoim miło im było patrzać na kochanego ojca, tak i w śmierci nierozdzielnie z nim złączyć się chciały i onego w ostatecznym życia jego punkcie nie odstąpiły ${ }^{109}$.

Ponownie mamy do czynienia $\mathrm{z}$ argumentem dowodzącym jednej z cnót panieńskich - miłości do rodziców. Tym razem jednak panienki ukazane są w akcie składania pamięci ojca heroicznej ofiary z samych siebie.

Równie mało powściągliwą wyobraźnią wykazał się jezuita Aleksander Elisz w końcu stulecia na pogrzebie Zofii Engracji Hulewiczówny ${ }^{110}$, córki Jerzego Stanisława, herbu Nowina, wojskiego włodzimierskiego i sędziego grodzkiego łuckiego, oraz Ewy Katarzyny z Peretiakowiczów. Dla tego kaznodziei, podobnie jak dla wcześniej cytowanych, oba plany - historyczny i alegoryczny - stanowity równorzędne źródła argumentów pochwalnych. Enkomion zawiera zarówno wyliczenie koligacji, pochwałę ex meritis poszczególnych przodków, alegoryczne obrazy mobiliów herbowych ${ }^{111}$, jak i realne ukazanie laudaty ${ }^{112}$ :

Ten obraz panieńskiego wychowania wielkiej pewnie sztuki widzieć było uformowany na Jej M[o]ści Pannie sędziance łuckiej. Widzieć ją było zawsze abo w rodzicielskim, abo Bogu poświęconym domu, wszędzie roztropną i ostrożną i samego niebo piastującego Boga w sercu i uściech noszącą. Precz były od niej wszelkie świegotliwości, ustawnie z Bogie[m] abo o Bogu rozmawiającej ${ }^{113}$. [--]

Pamiętam, co ja, coście i wy przede mną niemniej prawdziwie, jako i żałośnie o córce waszej, rodzice, mówili: „Myśmy rozumieli, żeśmy nie

109 M. Lisicki, Eódź do szczęśliwego portu ptynąca, k. Fver.

110 Por. K. Niesiecki, Herbarz polski, t. 4, wyd. J. N. Bobrowicz, Lipsk 1839, s. 392. Niesiecki zna tylko drugie imię zmarłej.

111 Na przykład: „Patrz jeszcze na jej ojczyste klejnoty, w herbownym uchu [mobilium herbu Nowina] jej domu zacność, w mieczu jej przyzwoita dzielność, górę trzymają, na których gdy koronę, a w niej uklękającego, znać się do nieba mającego, Złotogoleńczyka widzisz, to opowiedz i tym wszelkie żale zabijaj”, A. Elisz, Góry ukoronowane, k. A, rec.; „Hulewiczowski mieczu, żeś dobrze na nieprzyjacielskich karkach przytępiony i dlatego górę nad uchem nie wszystkę sławę twoję pojąć mogącym i koronę trzymający, izali i ty wyżej ukoronowanymi górami Jej M[o]ści Panny Zofii Hulewiczównej, sędzianki łuckiej nie prowadzisz? Wiem, żeś i w jej rękach nie próżnował, zwycięskiemi laurami do niebieskiej korony jej torując droge", ibidem, k. Fver.-F 2 rec.

112 U. Kicińska (eadem, Wzorzec szlachcianki, s. 290, tab. 1, poz. 22) wymienia: udział we mszach świętych, przyjmowanie sakramentów, praktykowanie postów i modlitwę.

113 A. Elisz, Góry ukoronowane, k. E2ver. 
człowieka, ale anioła w domu naszym mieli”. Ja zaś tak mówię: wyście ją urodzili człowiekiem, aleście ją wychowaniem uczynili aniołem. [--] Tak i wy mogliście zawsze z radością mówić, tym sobie teraz żale wasze cieszący rodzice, gdyście widzieli, jako z młodu zaraz, niczym córkę waszę świat nie powabiał, jako jej wszystkie najukochańsze zabawy były mieć się ustawnie do Boga swojego i do niego przez owe koronki, przez owe z różańcowych, z kwiatków lilijowych, z raju dusznego kwiatów uwite, przez złote korony nabożeństwem przychodzić ${ }^{114}$.

To zaledwie dwa krótkie wyjątki spośród bardzo licznych pochwalnych passusów (elementy enkomiastyczne, głównie z planu symbolicznego, są bowiem w całym kazaniu). Elisz nie odwołuje się w tym miejscu do abstrakcyjnych pojęć (takich jak np. pobożność czy skromność), ale pragnie przypomnieć słuchaczom konkretne obrazy i słowa z przeszłości: „widzieć było”, „coście mówili”, „gdyście widzieli”, których byli lub mogli być świadkami.

Nie dość na tym. Elisz pozwala pannie przemówić własnym głosem:

Widzieć było nim [mieczem herbowym] odcięte wszelkie w pokarmach wygody, że kiedy już postu zataić przed rodzicami, abo go sobie u nich uprosić nie mogła, ostatnie tego dokazywała mówiąc: „Na cóż to ciało karmić, które ono nie za długo jeść robacy będą!"115.

Urszula Kicińska zacytowała tę wypowiedź w swojej monografii poświęconej wzorcom osobowym szlachcianek w siedemnastowiecznych kazaniach ${ }^{116}$, ale ponieważ nie badała kazań w perspektywie komparatystyki genologicznej, nie mogła też dostrzec szczególności passusów tego typu. Panna, której dozwolono przemówić, to w patriarchalnej, tradycyjnej kulturze szlacheckiej rara avis ${ }^{117}$, nawet jeśli jej „wystąpienie" ograniczało się do jednego zdania. W mowach szlacheckich oratorzy nie cytowali autentycznych wypowiedzi laudat ${ }^{118}$.

114 Ibidem, k. Frec.-ver.

115 Ibidem, k. Gver.

116 Por. U. Kicińska, Wzorzec szlachcianki, s. 294.

117 Kobiety w dobie staropolskiej były „ceremonialne nieme”, zdarzało się jednak, że przemawiały w sądach; zob. M. Trębska, Orator w podwice - o staropolskich przemowach kobiet, „Kwartalnik Historii Nauki i Techniki”, 2012, 3-4, s. 145-153. Panny natomiast mogły, jeśli w ogóle, zabrać głos wyłącznie w trakcie ceremonii własnych obłóczyn; zob. M. Ciszewska, Tuliusz domowy, s. 207.

118 W całym dorobku funeralnym Jakuba Sobieskiego (idem, VIII. Dziękowanie na pogrzebie Anny Ostrogskiej z Kostków, w: idem, Mowy pogrzebowe, s. 101-102, XVIII,17), jednego z najwybitniejszych oratorów pierwszej połowy XVII w., jest jedno tylko sermocinatio: niewyrażona faktycznie nigdy, hipotetyczna myśl (a nie wypowiedź) księżny Ostrogskiej (matrony) o przyszłości jej potomstwa. 
Panny realizowały $\mathrm{w}$ praktyce jedną z najważniejszych cnót dziewiczych: małomówność. W kazaniach bynajmniej nie unikano figury sermocinatio: laudata mogła czynić wyznania i wygłaszać umoralniające sentencje ${ }^{119}$ - wszystko w obrębie wzorca pobożności i chrześcijańskiej cnoty.

Kaznodzieje starali się wywiązać ze swych krasomówczych obowiązków nawet w przypadku pochwały noworodka. Oto przykład wstępu do laudacji Krystyny Pacówny, córki Feliksa Jana, cześnika litewskiego i jego pierwszej żony Anny Konstancji Zawiszanki ${ }^{120}$ :

Kończyć czy milczeć o trzeciej peregrynce, Krystynie Pacównie, J[aśnie] W[ielmożnej] J[ej] M[ości] Paniej wojewodziny trockiej wnęczce, a podkomorzance W[ielkiego] Ks[ięstwa] L[itewskiego], deliberuję, bo zechcę-li tej, która ledwie dwa kroki uczyniła, jeden z żywota matki na świat, drugi zarazem w grób za matką, ślad pokazować, nie sfatyguję łask waszych $\mathrm{u}$ siebie. Jeżeli zaś będę chciał dzieciny jednej z wielu zacnych familij ozdobę troczyć1 ${ }^{121}$, ocean to na mię niezbrodzony, bo odpuść Wielmożne M[ił]ościwe Państwo, w kościele kronik politycznych nie masz, herbów nie pytać, gotowe do kościołów noszą ${ }^{122}$.

Noworodka nie można chwalić ani za dokonania, choćby najbardziej metaforycznie przedstawione, ani za cnoty. W panegiryzmie Piotrkowczyk pozostaje więc wiarygodny, gdyż przedstawia swoje rozterki jako mówcy zobowiązanego tradycją do amplifikacji określonych toposów, ostatecznie decyduje się na obszerny enkomion pochodzenia

119 W mieszczańskim kazaniu Andrzeja Schoenflissiusa (idem, op. cit.) w części Personalia, znajdujemy liczne, potwierdzone świadectwem kaznodziei wypowiedzi dwunastoletniej Anny Dębowskiej, w trakcie jej śmiertelnej choroby, np.: „Nie frasujcie się o mnie rodzicy moi, będzie-li mię Pan chciał tu zostawić, niech się dzieje święta wola Jego, a jeśli mię też chce z tego świata wziąć, nie zginę wiecznie, dusza moja dostanie się do radości wiecznych, tam was czekać będę”, ibidem, k. $\mathrm{C}_{2}$ ver.; „Namilsza pani matko, już czas, abym duszę swą opatrzyła, dwanaście lat na świecie żyję, czas mi do komunijej ś[więtej], bo co wiedzieć, jeśli z tej choroby wstanę. Poślejcie mi po spowiednika, abym się z Panem Bogiem pojednała i duszę swoję Sakramentem ś[więtym] posiliła", ibidem, k. $\mathrm{C}_{2}$ ver.- $\mathrm{C}_{3}$ rec. Podobne elementy w kazaniu W. Czarnockiego: Malogranat abo Kazanie przy egzekwiach Jaśnie Oświeconej Jej Mci Paniej P. Anny z Sztemberku Księżny Ostrogskiej, hrabinej na Tarnowie, wojewodzinej wotyńskiej, miane w Jarostawiu, $w$ kościele ś. Mikotaja panien zakonnych ś. Benedykta [--] 9 stycznia roku Pańskiego 1636 [--], Kraków [1636].

120 Brak wzmianki o Krystynie u Niesieckiego; idem, op. cit., t. 7, s. 222.

121 troczyć - odczytanie niepewne.

122 A. Piotrkowczyk, Zawitanie trzech osób, k. $\mathrm{D}_{2}$ ver. 
dziewczynki. Dodać tu należy, że pochwała ta następuje na samym końcu mowy, która była poświęcona jednocześnie zmarłym babce i matce Krystyny, jest więc pewnym naddatkiem należącym wyłącznie do cząstki laudacyjnej dziecka.

Przedstawione tu zestawienie oracji świeckich i kazań wygłoszonych na pogrzebach dziewcząt i panien, choć z pewnością nie dość szczegółowe, pozwala jednakże wskazać podobieństwa i zasadnicze różnice $\mathrm{w}$ przedstawieniu laudat i amplifikacji tematu cnót $\mathrm{w}$ obu tych gatunkach funeralnych. Podobny jest niewątpliwie katalog cnót, którymi winna się odznaczać panna, co wynika z powszechnie przyjętego wzorca osobowego. W kilku zaledwie cytowanych przykładach oratorzy szlacheccy uzupełnili ten model o wierność i miłość do królowej i do Ojczyzny. Przypisanie takich „obywatelskich” cnót pannie pozwala wynieść ją ponad sferę rodzinną czy też prywatną, w której była tradycyjnie portretowana. Nie jest jednak wykluczone, że gdyby $\mathrm{z}$ pogrzebu dwórki zachowało się kazanie, również w nim można byłoby znaleźć analogiczne pochwały.

Rozbieżności jest natomiast zdecydowanie więcej i są one jaskrawsze. Pomijając dość oczywiste kwestie objętości tekstów (kilkustronicowe mowy szlacheckie i liczące dziesiątki stron druki kazań), a co za tym idzie także enkomionów, należy podkreślić przede wszystkim różnice w amplifikacji toposów pochwały. Cnotę pobożności wzorem mówców szlacheckich można nazwać pobożnością, ale można też jak czynili to kaznodzieje - jej dowodzić: przez sermocinatio, opowiedzenie o zwyczajach i dewocyjnych praktykach laudaty czy fikcyjnych, mniej lub bardziej heroicznych czynach dokonanych w planie symbolicznym. Paradoksalnie też więcej biograficznych informacji o zmarłych można znaleźć w kazaniach niż w mowach szlacheckich.

Widoczna jest tu również dysproporcja w rozwoju gatunków i w przemianach języka. Tendencję do rozbudowanej ornamentacji heraldycznej obserwujemy w kazaniach już z pierwszej połowy XVII w., podczas gdy w oratorstwie szlacheckim zjawisko to będzie stopniowo narastać (nie jest wykluczone, że właśnie pod wpływem wymowy kościelnej) dopiero w drugiej połowie stulecia. Język mów świeckich, w czasach Jakuba Sobieskiego czy Jerzego Ossolińskiego wyrazisty, acz wolny od nadmiernej ozdobności, z biegiem lat ewoluował w kierunku, który wskazywało już cytowane tu dziękowanie 
Aleksandra Ogińskiego (z 1660). W drugiej połowie stulecia mówcy świeccy posługiwali się figurami oddziałującymi silnie na wyobraźnię słuchaczy ze szczególnym upodobaniem w mowach obłóczynowych, tj. wygłaszanych w czasie uroczystości przyjmowania panny do nowicjatu $^{123}$. Probantki podobnie jak laudaty kazań funeralnych stawały się heroinami, które nadludzkim wysiłkiem wiodty batalie (nierzadko $\mathrm{z}$ "herbownym” mieczem $\mathrm{w}$ dłoni) $\mathrm{z}$ ciałem, światem i szatanem ${ }^{124}$.

Wszystkie przedstawione $\mathrm{w}$ niniejszym studium spostrzeżenia odnoszące się do różnic między kazaniami i mowami szlacheckimi znajdują potwierdzenie w tekstach funeralnych poświęconych mężatkom i wdowom. Wystarczy porównać szlacheckie mowy Jakuba Sobieskiego na pogrzebach Reginy Żółkiewskiej i Anny Ostrogskiej z ich kościelnymi odpowiednikami - m.in. kazaniami Wojciecha Gizy i Wojciecha Czarnockiego ${ }^{125}$, aby wskazane tu odmienności zarysowały się nawet jeszcze wyraźniej, wydaje się więc, że można mówić o pewnej prawidłowości.

\title{
Bibliografia
}

\author{
Źródła archiwalne
}

Biblioteka Jagiellońska w Krakowie: rkps 6092

Biblioteka Muzeum Narodowego im. Czartoryskich w Krakowie: rkps 1679 IV

123 O gatunkach mów obłóczynowych zob. M. Ciszewska, Tuliusz domowy, s. 133-208 .

124 Szczegółowe analizy w: M. Trębska, Odważna Judyt i mężna w Bogu Amazonka, czyli o walce duchownej $w$ staropolskich oracjach obtóczynowych, w: Wojny, bitwy i potyczki, red. M. Piskała, W. Pawlak, Warszawa 2011, s. 373-386.

125 J. Sobieski, VII. Dziękowanie na pogrzebie Reginy Żótkiewskiej z Herburtów, kanclerzyny i hetmanowej wielkiej koronnej, w: idem, Mowy pogrzebowe, s. 61-63; idem, VIII. Dziękowanie na pogrzebie Anny Ostrogskiej z Kostków, w: ibidem, s. 100-106; W. Giza, Kazanie żatobne na pogrzebie Jaśnie Wielmożnej Paniej Jej Mci Paniej Reginy Żótkiewskiej z Felsztyna, kanclerzynej i hetmanowej wielkiej koronnej, [--] odprawione w Żótkwi dnia 17. grudnia roku P. 1624 [--], Zamość 1625. O laudacjach kobiet w oracjach J. Sobieskiego zob. M. Ciszewska, The Encomium of Polish Noblewomen in Jakub Sobieski's Secular Funeral Speeches (the First Half of the 17 $7^{\text {th }}$ Century), „Annales Universitatis Mariae Curie-Skłodowska", Sectio FF, 38, 2020, 2, s. 15-25. Mowy Sobieskiego, choć na tle jego dorobku wydają się mieć rozwinięte enkomiony, w porównaniu z laudacjami tych samych osób w kazaniach wręcz zaskakują powściągliwością i oszczędnością - również biograficzną. 
Biblioteka Muzeum Narodowego w Krakowie: rkps 187; 425 III

Biblioteka Narodowa w Warszawie: rkps 6640

Biblioteka Zakładu Narodowego im. Ossolińskich we Wrocławiu: rkps 4589 I

Lietuvos valstybes istorijos archyvas (Litewskie Państwowe Archiwum Historyczne w Wilnie): f. 1135, op. 2/40

\section{Źródła drukowane}

Aleksander à Jesu (Andrzej Kochanowski), Plastr miodu od śmierci pożarty, ale śmierci wydarty, to jest kazanie na pogrzebie Jej Mci Panny Barbary Lanckorońskiej, kasztelanki kamienieckiej, Jaśnie Wielmożnego Jego Mci P. Stanistawa z Brzezia Lanckorońskiego, wojewody bractawskiego [--], kochanej córki miane [--] die 23. Novembris, anno 1649. Do druku podane za dozwoleniem Starszych, [Kraków 1649]

Czarnocki W., Malogranat abo Kazanie przy egzekwiach Jaśnie Oświeconej Jej Mci Paniej P. Anny z Sztemberku Księżny Ostrogskiej, hrabinej na Tarnowie, wojewodzinej wotyńskiej, miane $w$ Jarostawiu, $w$ kościele ś. Mikotaja panien zakonnych ś. Benedykta [--] 9 stycznia roku Pańskiego 1636 [--], Kraków [1636]

Elisz A., Góry ukoronowane Jej Mść Pannę Zofiją Engracyja Hulewiczównę, sędziankę tucka, na wesele niebieskie wynoszące, przy ziemskich z jej odeścia zalach pogrzebowym kazaniem ogtoszone w kościele tuckim Societatis Jesu nazajutrz po święcie nawiedzenia Najświętszej Panny, roku z Gór Niebieskich zniżonego Boga 1698 [--], Lwów [1698]

Giza W., Kazanie żatobne na pogrzebie Jaśnie Wielmożnej Paniej Jej Mci Paniej Reginy Żótkiewskiej z Felsztyna, kanclerzynej i hetmanowej wielkiej koronnej, [--] odprawione w Żótkwi dnia 17. grudnia roku P. 1624 [--], Zamość 1625

Grzegorz z Nyssy, Wybór pism, tł. W. Kania, Warszawa 1974 (Pisma Starochrześcijańskich Pisarzy, t. 14)

Lisicki M., Eódź do szcześliwego portu ptynąca, przy pogrzebinach Jego Mości Pana, P. Jana Szotdrskiego, cześnika ziemskiego kaliskiego, także Ich Mościów Panien Barbary i Jadwigi, dwu cór Jego Mości, Szotdrskich, kazaniem żatobnym [--] w kościele czempińskim dnia 11. grudnia, w roku Pańskim 1662. [--] wyprawiona, Poznań [1633]

Menander Rhetor, ed., transl., comm. D. A. Russell, N. G. Wilson, Oxford 1981

Piegłowski R., Pokój i nieśmiertelność Jaśnie Oświeconego Wtodzimierza Swatopetka, Ksiażęcia Czetwertyńskiego, starosty siewińskiego, i rodzonych jego: Teresy i Krystyny, chorażanek wotyniskich, na jednym katafalku [--] wystawionych [--], Kraków 1675

Pigłowski W., Rzeka pokoju i strumień powódź stawy niosący, to jest: Kazanie na pogrzebie Wielmożnej Jej Mości Paniej Konstancyjej z Lubomirza Czarnkowskiej, międzyrzeckiej, pyzdrskiej, etc. starościnej, miane w kościele 
czarnkowskim przez Ks[iędza] Wojciecha Pigtowskiego, kanonika poznańskiego, wateckiego proboszcza, I. Octobr. 1646, Poznań 1646

Piotrkowczyk A., Zawitanie trzech osób: Jaśnie Wielmożnej Jej Mości Paniej Elżbiety Szemetówny Pacowej, wojewodzinej trockiej [--], Wielmożnej Jej Mości Paniej Anny Konstancyjej Zawiszanki, podkomorzynej W.KS.L. [--], Wielmożnej Jej Mości Paniej Krystyny Pacówny, podkomorzanki W.Ks.L. do grobu chwalebne, [--] zambony wileńskiej roku P. 1652. dnia 15 Octobra kazaniem ogtoszone, [Wilno 1652]

Schoenflissius A., Córa Jairowa zmarta, od Chrystusa wzbudzona, na pogrzebie cnej i pobożnej Panny Anny Dębowskiej, szlachetnego Pana Marcina Dębowskiego, aptekarza i mieszczanina wileńskiego, najmilszej i jedynej córki wystawiona w Wilnie, na cmintarzu [sic] saskim roku Pańskiego, 1635. 4. maja. [--], b.m. 1635

Sierakowski J., Prezenta wielocnót przezacnego domu Berżewiców i Jaśnie Urodzonej Panny Jej Mci Panny Marianny Berżewicewnej w Księstwie Pruskim na Lisnowie za żywota, nadzieja, że i pośmierci w Niebieskim Indygenacie pewnej dziedziczki, w kościele lisnowskim przy pogrzebowym akcie, na wtórych obsekwiach siódmego dnia października roku Pańskiego 1648 [--], Toruń b.d.

Sobieski J., Mowy pogrzebowe, wyd. M. Barłowska, M. Ciszewska, Warszawa 2019

Spizarnia aktów rozmaitych, które się przy zalotach, weselach, bankietach, pogrzebach i tym podobnych inszych zabawach swieckich odprawować zwykty [--], Kraków 1638

Szymusiak J. M., SJ, Grzegorz Teolog. U źródet chrześcijańskiej myśli w IV wieku, przedm. H. de Lubac SJ, Poznań 1965 (Starożytna Myśl Chrześcijańska, t. 1)

Turnowski J., Pogrzebne stowa wyrzeczone nad zacnym ciatem J. M. Panny Anny z Krotoszyna Krotoskiej, etc. [--], roku Naświętsz. Pana N. (I) I) (VI dnia 4 maja, Gdańsk 1606

Węgierski T., Kazanie pogrzebne, sposób chrześsijańskiej żatoby i w niej przedniejsze z pism sś. pociechy wyrażające, nad zacnym ciatem st. pamięci J.W.P. Jej Mści Panny Aleksandry hrabianki z Leszna Leszczyńskiej, wojewodzanki betskiej, etc. etc., we Wtodawie [--] XVII dnia maja roku Pańskiego MDCXXIV odprawione [--], Lubcz 1625

Wojsznarowicz K., Orator polityczny, weselnym i pogrzebowym stużacy aktom, tak stanowi duchownemu, jako rycerskiemu potrzebny [--], na trzy częśi rozdzielony [--], Kraków 1648

Zielejewicz E., Kazanie umartych do żywych, które miaty kości zmartych $w$ Chrystusie Jej Mości Paniej Anny Szczytówny Zabielskiej, Kasprowej Towiańskiej, sędzinej witkomirskiej, grodzkiej, i Jej Mości Panny Reiny Towiańskiej, sędzianki witkomirskiej oraz, w kościele witkomirskim die 24. [Octo]bris anno 1651 grzebionych [--], Vilnae [1651] 


\section{Opracowania}

Baczewski S., Mit poczatku i wtadza szlachty. Dyskurs genealogiczno-historyczny w XVII-wiecznych kazaniach pogrzebowych, „Wschodni Rocznik Humanistyczny", 3, 2006, s. 37-55

Barłowska M., „Nasz Kochanowski”. Studia z recepcji poety w wieku XVII, Katowice 2014

Barłowska M., Swada i milczenie. Zbiory oratorskie XVII-XVIII wieku - prolegomena filologiczne, Katowice 2010

Bieńkowski T., Proemium (Antyczna teoria wstępu do mowy), „Meander”, 1965, 1, s. 12-34

Bogucka M., Biatogtowa $w$ dawnej Polsce. Kobieta $w$ spoteczeństwie polskim XVI-XVIII wieku na tle porównawczym, Warszawa 1998

Bourbouhakis E. C., Not Composed in a Chance Manner. The Epitaphios for Manuel I Komnenos by Eistathios of Thessalonike, Uppsala 2017 (Acta Universitatis Upsaliensis. Studia Byzantina Upsaliensia, t. 18)

Burrus V., Life after Death. The Martyrdom of Gorgonia and the Birth of Female Hagiography, w: Gregory of Nazianzus. Images and Reflections, ed. J. Børtnes, T. Hägg, Copenhagen 2006, s. 153-170

Charewiczowa Ł., Kobieta $w$ dawnej Polsce: do okresu rozbiorów, Poznań 2002

Chrościcki J. A., Pompa funebris. $Z$ dziejów kultury staropolskiej, Warszawa 1974

Ciszewska M., The Encomium of Polish Noblewomen in Jakub Sobieski's Secular Funeral Speeches (the First Half of the 17 $7^{\text {th }}$ Century), "Annales Universitatis Mariae Curie-Skłodowska", Sectio FF, 38, 2020, 2, s. 15-25

Ciszewska M., Modestia mtodego mówcy (XVII-XVIII wiek), w: Sarmackie theatrum, VIII. W poszukiwaniu nowości, red. M. Barłowska, M. Walińska, Katowice 2020, s. 26-49

Ciszewska M., Tuliusz domowy. Świeckie oratorstwo szlacheckie kręgu rodzinnego (XVII-XVIII wiek), Warszawa 2016

Danowska E., Wojtowicz J., Kazania i mowy pogrzebowe w XVIII wieku na podstawie starodruków Biblioteki Naukowej PAU i PAN w Krakowie, w: Europejski wiek osiemnasty. Uniwersalizm myśli, różnorodność dróg. Studia $i$ materiaty, Warszawa-Kraków 2014, s. 523-532

Dworzaczkowa J., Krotoski (Krotowski) Jan h. Leszczyc, PSB, 15, 1970, s. 344-345

Genealogia [2]. Tablice, oprac. W. Dworzaczek, Warszawa 1959

Górecka K., Pobożne matrony i cnotliwe panny. Epitafia jako źródto wiedzy o kobiecie w epoce nowożytnej, Warszawa 2006

Gruszecki S., Minski Stanistaw, PSB, 21, 1976, s. 320-322

Hägg T., Playing with Expectations. Gregory's Funeral Orations on His Brother, Sister and Father, w: Gregory of Nazianzus. Images and Reflections, ed. J. Børtnes, T. Hägg, Copenhagen 2006, s. 133-151 
Jarczykowa M., Sponsorowana pochwata. Funeralia Radziwittowskie z XVII wieku napisane na zamówienie, „Napis”, 25, 2019, s. 19-36

Kahl E., Wychowanie dziecka w rodzinie szlacheckiej w XVI i XVII wieku, „Wychowanie w Rodzinie”, 1, 2011, s. 19-38

Kicińska U., Pobożność szlachcianki w świetle polskich drukowanych mów pogrzebowych XVII wieku, „Folia Historica Cracoviensia”, 18, 2012, s. $213-237$

Kicińska U., Wzorzec szlachcianki w polskich drukowanych oracjach pogrzebowych XVII wieku, Warszawa 2013

Kuchta J., W godności $i$ w cnoty dojrzate - o wzorcu panny, żony $i$ dobrego matżeństwa w literaturze okolicznościowej XVII-XVIII wieku, „Annales Universitatis Paedagogicae Cracoviensis”, Folia 95, Studia Historica, 10, 2011, s. 57-65

Maciszewski J., Kryski Feliks vel Szczęsny, PSB, 15, 1970, s. 482-485

Małunowiczówna L., Konsolacja $w$ mowach pogrzebowych św. Grzegorza z Nyssy, „Roczniki Humanistyczne”, 23, 1975, 3, s. 73-103

McGuire M. R. P., The Early Christian Funeral Oration, w: Funeral Orations by Saint Gregory Nazianzen and Saint Ambrose, transl. L. P. McCauley SJ, J. J. Sullivan C.S.Sp., M. R. P. McGuire, R. J. Deferrari, Washington 2017 (repr. ed. 1968) (The Fathers of the Church, t. 22)

McManamon J. M., SJ, Funeral Oratory and the Cultural Ideals of Italian Humanism, Chapel Hill 1989

McManamon J. M., SJ, An Incipitarium of Funeral Orations and a Smattering of Other Panegyrical Literature from the Italian Renaissance (ca. 1350-1550), http://www.luc.edu/media/lucedu/history/pdfs/Incipit_Catalogue. pdf (9 III 2016)

Niesiecki K., Herbarz polski, t. 2, 4, 6, 7, 8, 9, wyd. J. N. Bobrowicz, Lipsk 1839-1845

Nowicka-Struska A., Obrazy kobiety i kobiece wzorce osobowe w siedemnastowiecznych kazaniach pogrzebowych autorstwa karmelitów bosych, „Wschodni Rocznik Humanistyczny", 3, 2006, s. 57-68

Ochmann S., Pogrzeb magnata $w$ XVII wieku w świetle rachunków, w: $Z$ dziejów i tradycji Srebrnego Wieku. Studia i materiaty, red. J. Pietrzak, Wrocław 1990 (Acta Universitatis Wratislaviensis. Historia, t. 75, nr 1108), s. 73-82

Pernot L., Epideictic Rhetoric. Questioning the Stakes of Ancient Praise, Austin 2015

Platt D., Kazania pogrzebowe z przetomu XVI i XVII wieku. Z dziejów prozy staropolskiej, Wrocław 1992

Rachuba A., Mikotaj Krzysztof, w: Dom Sapieżyński, t. 1, oprac. E. Sapieha, Warszawa 1995, s. 335-336

Sipayłło M., Leszczyński Rafat h. Wieniawa, PSB, 17, 1972, s. 135-139

Skwara M., „Miejsca wspólne” polskiej poezji i sztuki funeralnej XVI i początku XVII wieku, Szczecin 1994 
Skwara M, O dowodzeniu retorycznym w polskich drukowanych oracjach pogrzebowych XVII wieku, Szczecin 1999

Skwara M., Polskie drukowane oracje pogrzebowe XVII wieku. Bibliografia, Gdańsk 2009

Starnawski J., Wstęp, w: M. Kromer, Mowa na pogrzebie Zygmunta I oraz O pochodzeniu i o dziejach Polaków ksieggi XXIX i XXX, oprac. J. Starnawski, Olsztyn 1982, s. I-XXXI

Starnawski J., Wstęp, w: S. Orzechowski, Wybór pism, oprac. J. Starnawski, Wrocław 1972, s. I-XVIII

Trębska M., Odważna Judyt i mężna w Bogu Amazonka, czyli o walce duchownej w staropolskich oracjach obtóczynowych, w: Wojny, bitwy i potyczki, red. M. Piskała, W. Pawlak, Warszawa 2011, s. 373-386

Trębska M., Orator w podwice - o staropolskich przemowach kobiet, „Kwartalnik Historii Nauki i Techniki”, 2012, 3-4, s. 145-153

Trębska M., Staropolskie szlacheckie oracje weselne. Genologia, obrzęd, źródta, Warszawa 2008

Wyrobisz A., Staropolskie wzorce rodziny $i$ kobiety - żony i matki, „Przegląd Historyczny", 83, 1992, 3, s. 405-421

Żołądź-Strzelczyk D., Dziecko w dawnej Polsce, Poznań 2002

\section{The Lassies and Maidens in the Funeral Noble Speeches and Sermons (Seventeenth Century)}

The article presents a comparative analysis of maiden encomia in seventeenth-century funeral eulogies of the nobility and in sermons. In the oratorical tradition, women were praised above all ex virtutis, which corresponded to the traditional personal role model of a maiden, married woman, mother, and a widow remaining in the private sphere, within the circle of family. The juxtaposition of texts from two different genres has proved the existence of fundamental differences between laudations delivered by lay speakers and preachers. The catalogue of maiden virtues in the Old Polish era was relatively modest and limited to just a few values. However, while the praises of the nobility, especially from the first half of the seventeenth century, should be considered very sparing, as they were usually reduced to an enumeration of virtues of the praised maiden, religious speakers amplified the topic of each virtue, proving it with biographical examples (either from a biographic or symbolic plan). As a result, the authors of sermons were able to create the semblance of praise ex meritis usually applied to men. The source basis for the study were the texts of sixteen noble orations (five historical speeches and eleven rhetorical examples) and nine published sermons. 
Dr hab. Małgorzata Ciszewska - prof. Instytutu Badań Literackich PAN, od 2009 r. zatrudniona w Pracowni Literatury Renesansu i Baroku IBL PAN, specjalizacja: historia literatury. Zainteresowania badawcze: staropolskie oratorstwo okolicznościowe, epistolografia, edytorstwo.

Małgorzata Ciszewska - PhD with habilitation, professor of the Institute of Literary Research of the Polish Academy of Sciences, since 2009 employed in the Literature of the Renaissance and Baroque Section of the ILR PAS. She specialises in history of literature, her research interests include Old Polish occasional oratory, epistolography, editing.

E-mail: malgorzata.ciszewska@ibl.waw.pl 